\title{
EPIGRAPHY AND ISLAMIC HISTORY IN SOUTH ASIA *
}

\author{
Dr. Mohammad Yusuf Siddiq
}

\begin{abstract}
One of the great intellectual achievements and significant contribution of Islamic civilization to the science of historiography is its rich legacy of historical texts not being limited to chronicles and books but in other forms, including inscriptions. These inscriptions which were used in Islamic culture since its formative period are a mode of cultural expression and reflect the Islamic faith itself. The earliest Islamic inscriptions date from the first/seventh century. It is difficult to imagine a building of the early period without some kind of inscription -- as if, without one, the building would be unfinished or 'naked'. However, approaching Islamic inscriptions in a systematic way with an academic interest began in the late nineteenth century, when Islamic epigraphy saw some of its rules codified as a result of the dedicated efforts of the famous Swiss orientalist Max Van Berchem (1863-1923) who can be regarded as the pioneer of the science of modern Islamic epigraphy in this age. The article deals with the history and importance of Epigraphy in detail. It also encompasses the comparison of inscriptions of Andalusia and Bengal.
\end{abstract}

Key Words: Historiography, Inscriptions, Epigraphy, Bengal, Andalusia

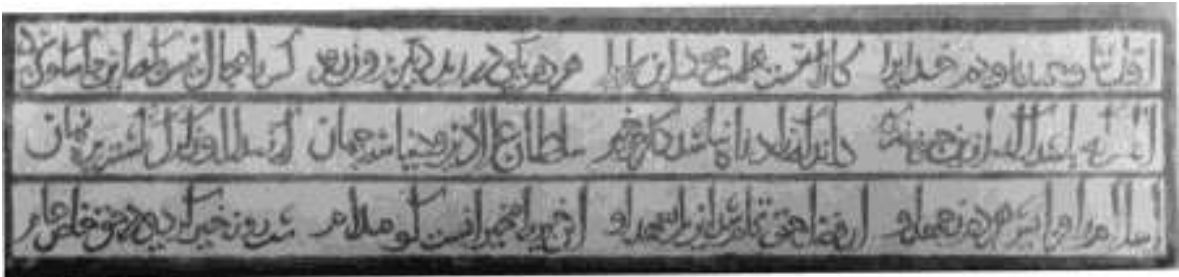

Plate: Bridge inscription in tawq'̄'style from the reign of Sultan 'Alā' Dīn Khalji, the 2nd ruler of Bengal $c ., 1210-1213$ CE.

\footnotetext{
* This study was made possible through generous grants from Iran Heritage Foundation, London, U.K., Foundation Max Van Berchem, Geneva, Switzerland, and Higher Education Commission, Islamabad, Pakistan. This is a revised and expanded version of a previously published article.
} 
In the beginning, I praise and thank God, the One Who in His (divine) wisdom has provided this inn (-like world). At every moment someone is entering into it, while someone else is departing; for no one has the capacity to settle here permanently.

As soon as someone becomes aware of the rapid movement of the cosmos, he soon realizes that there is no other provision for the way [of life] except good deeds. Due to the justice of Sultan 'Ala' Din wa Dunya' shah-e-Jahan (the king of the world), even a lamb does not (need to) hide from a wolf. Because of his efforts, Islam grows every moment. By the mercy of (God) the Just, this bridge was completed during his reign. This good action is possible only by the one who is day and night continually engaged in acts of benevolence for everyone -- the noble as well as the commoner.

\section{(The first Islamic inscription of Bengal)}

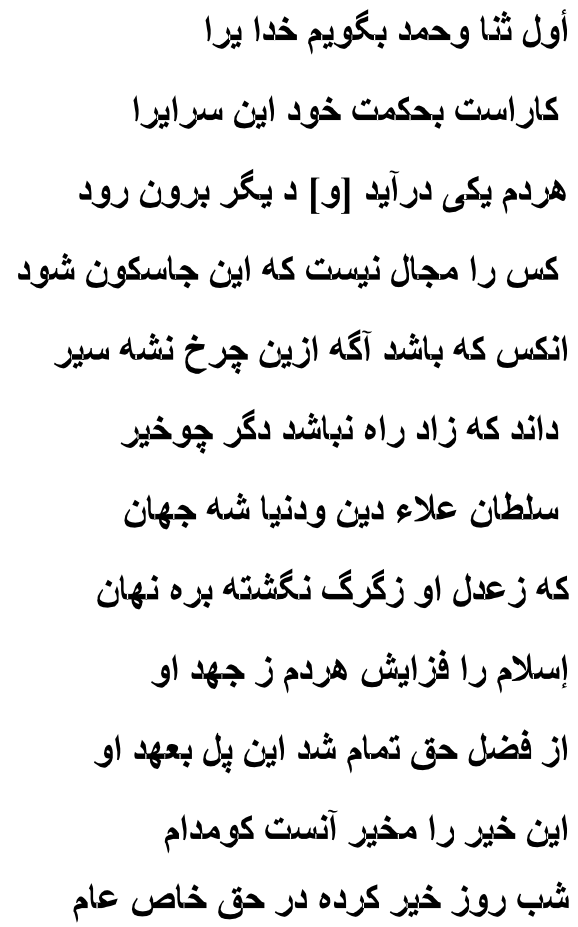

\section{EPIGRAPHY IN ISLAMIC TRADITION}

One of the great intellectual achievements of Islamic civilization and one of its significant contributions to the science of historiography is its rich legacy of historical texts. This historical output is not limited to chronicles and books on history (such as the Tabaqat [Biographical Dictionaries] of various writers ${ }^{1}$ ), but assumed other forms as well including inscriptions. Like most other modes of expression in this culture, these epigraphs reflect the Islamic faith itself. The extraordinary number of epigraphs also ensures the important role that inscriptions played in transmitting Islamic culture. Inscriptions can be found not only on buildings, but also on textiles and rugs, metal and glass objects, ceramics and ornaments, not to speak of arms, coins and seals. In some regions, a rich tradition of inscribing on stone existed even before the advent of Islam. Ibn Ishaq, for instance, mentions about a number of Syriac inscriptions which were unearthed while Ka'ba was demolished for reconstruction when the Prophet $S A W$ was about thirty-five years of age. During the Umayyad period, Muhammad ibn al-Sa'ib al-Kalbi (father of a famous early Muslim historian ibn-Hisham) took great interest in the Lakhmid stelae and funerary inscriptions that he found preserved in the churches in and around Kufa.

\footnotetext{
${ }^{1}$ For instance, Mawlana Minhaj al-Din Siraj al-Din, Tabaqāt-i-Nāsiri, ed. 'Abd al-Hay Habibi (Kabul, 1342 A.H.), provides much useful information about early Muslim rule in Bengal.
} 
The use of archaeological materials for scholarly investigation is encouraged in the Qur'an. The word Athar which can be found in the Qur'an at several places, is used in modern Arabic to mean archaeology. ${ }^{2}$ Archaeological findings offer many clues to the past; epigraphic studies reveal evidence of rulers who might otherwise have remained unknown. Thus we read in the sura (chapter) "Believers" in the Qur'an: "Do they not travel through the earth and see the end of those who had lived before them? They were more numerous than these and superior in strength and [ancient] remains in the land [where they had once lived]. Yet all that they accomplished was of no profit to them."3

\section{USE OF INSCRIPTIONS IN ISLAMIC ARCHITECTURE}

Inscriptions were used in Islamic culture since the formative period of Islam. The earliest Islamic inscriptions date from the first/seventh century. They became more common with increasing number of architectural projects in the Islamic world - it is difficult to imagine a building of the early period without some kind of inscription as if, without one, the building would be unfinished or 'naked'. As a result, epigraphic records and inscriptions are plentiful in terms of both artistic merit and historical information. Until the fourth/eleventh century, most appeared on the inside of buildings. After that century, however, inscriptions began to be used to decorate the exterior of buildings as well. During this period, the two styles of inscriptions, the cursive naskh and thulth, started to gain in popularity while use of the angular style known as Kufi (angular) declined. ${ }^{4}$

Calligraphic panels often constitute the most decorative elements in an Islamic building. As text, these inscriptions also conveyed messages. The use of written messages for architectural decoration may be described as a typical Islamic cultural phenomenon. However, in some buildings, the calligraphic panels are placed too high to be deciphered, ${ }^{5}$ suggesting that their aesthetic impact was more important than the textual message. In fact many early Kufi inscriptions and some Bengali tughra' (a highly intricate and stylized form of calligraphy) inscriptions from the Sultanate period in Bengal are almost indecipherable, again suggesting that aesthetics were more important than content. In regions influenced by Shi'ism, this development may to some extent have been inspired by its mystical tendency, especially the belief that a hierarchy of knowledge and spiritual development obtains among people so that not all inscriptions may or should be read by ordinary viewers. In a number of Islamic inscriptions, letters are easily confused and

\footnotetext{
${ }^{2}$ The celebrated Muslim historian Taqi al-Din Ahmad ibn 'Ali al-Maqrizi also uses the word $\bar{a} t h \bar{a} r$ to mean more or less the same thing in his treatise on the relics and remains of Cairo al-Khitat wa 'l-Athār (Cairo, 1370 A.H.).

${ }^{3} \mathrm{Al}$ Quran, 40: 82.

${ }^{4}$ One of the earliest examples of this development can be seen in the Qur'anic inscriptions on the tabut of al-Husayn made sometime around 550/1155 in Cairo, in which both Kufi and naskh are used; see Caroline Williams, "The Quranic Inscriptions on the tabut of al-Husayn," Islamic Art 2 (1987): 3-13. Another example is the Qutb Minar in Delhi built in early 13th century.

5 The inscription on the afar Khān's masjid dated 698/1298 in Tribeni, Hooghly; the Chhoto Sona Masjid inscription in Gaur from the reign of Husayn Shāh and Bagha Masjid inscription in the district of Rajshahi dated 930/1523-24 are examples of this kind of calligraphic program, where the inscriptions are placed too high to be easily read.
} 
uncertainties are created where the logic of the pattern of ornamentation takes precedence over legibility. ${ }^{6}$

However, it is also probable that with many inscriptions, some kind of historical intent was there from the very beginning. Perhaps they were intended to be read by future scholars, historians in particular. It is also possible that, being accustomed to the Kufi style, educated Muslims were more comfortable with the intricacies of $K u f i$ patterns, more so than with the cursive styles (like naskh) that we today consider easier. Kufi script enjoyed a higher status than cursive writing in those days. The selection of an appropriate position for the inscription on a monument was also important, since those parts of the monuments that were most easily seen best served the purpose.

In spite of the great importance that Islam attached to reading, writing and learning, the majority of the rural population in much of the Muslim world remained illiterate. However, the viewing of religious inscriptions, especially Qur'anic ones, was still a source of baraka (blessings). For the ordinary literate person, being able to recognize a text - say, the Throne Verse from the Qur'an or sayings of the Prophet on the virtues of building a masjid - was the important thing, and rather than being able to decipher it accurately and completely. Quite a few inscriptions therefore, served an iconographic function in place of the figurative imagery used in other traditions. Nevertheless, the vast majority of Islamic inscriptions can be called informative in that they provide some simple information such as date of construction, kind of structure, name of the personage by and for whom it was built, etc. Another common feature is certain reiterated formulas that recur in many Islamic inscriptions, in some cases repeated interminably. Since most of these formulas are phrases of religious import, they consciously reflect the dominant 'meaning' or 'message' with which the monument wants to be associated.

\section{EMERGENCE OF ISLAMIC EPIGRAPHY}

Inscriptions are found everywhere in the Muslim world from the Iberian Peninsula to the Indonesian archipelago. They were of sufficient interest to draw occasional notices by Muslim historians and writers from quite an early period. Al-Jahshiyari (d. 331/942), for instance, records a number of Arabic inscriptions on the gates of Acre and Sidon as well as on a treasury building in Azarbayjan. Ibn al-'Athir tells us that in 630 A.H., he saw in the court of the congregational mosque of Mosul a stone slab with an inscription which contained useful information about the extension of the mosque during the reign of the Abbasid Caliph Mahdi. Later, fourteenth-and fifteenth-century Arab scholars, such as Taqi al-Din Ahmad ibn 'Ali al-Maqrizi (d. 845/1441) and Taqi al-Din al-Fasi (775- 832/1374-1428) who taught at the famous Bengali seminary in Makkah, al-Madrasa al-Sultaniyyah alGhiyathiyyah al-Bangaliyyah, studied inscriptions as an important source for regional history. Al-Maqrizi deciphered, for instance, a complete waqf (endowment) inscription inscribed on al-Watatit well constructed under the patronage of vizier

${ }^{6}$ R. Ettinghausen, “Arabic epigraphy: communication or symbolic affirmation,” in Near Eastern Numismatics, Iconography, Epigraphy and History: Studies in Honor of George C. Miles, ed. D. K. Kouymjian (Beirut: American University of Beirut, 1974): 297-317. 
Abu 'l-Fadl. ${ }^{7}$ Al-Fasi's work was more methodical in dealing with the epigraphs of Makkah as he surveyed the architectural remains of this ancient city and deciphered their inscriptions. He cross-checked the dates appearing in the epigraphic texts with other historical sources to substantiate in a remarkably accurate way his findings about the history of Makkah. ${ }^{8}$ Still, the credit for making the study of inscriptions as a distinct discipline goes to Jamal al-Din Muhammad ibn 'Ali al-Shibi' (779837/1378-1433). His meticulous study of Makkan tombstones and stelae established for the first time a remarkably and unprecedentedly high standard for scholarly epigraphic study.

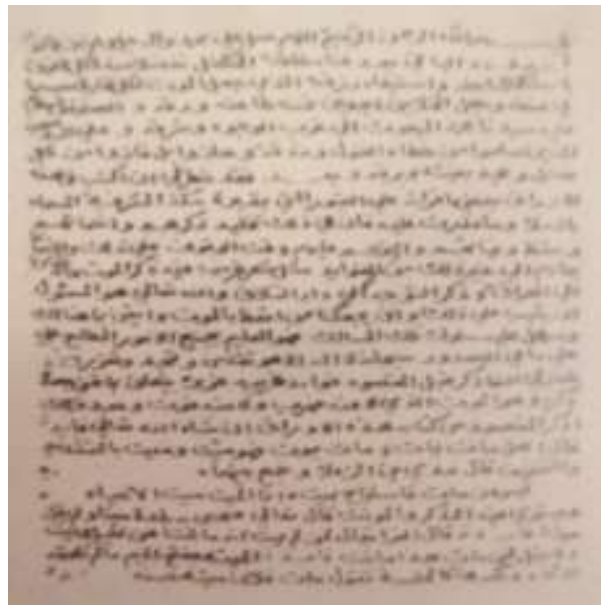

Another folio from al-Shibi's ms. al-Sharf $a l-A$ ' $l a$ '

\footnotetext{
${ }^{7}$ See, for instance, al-Khitat wa 'l-Athär (Cairo, 1370 A.H.) for details. This monumental work on the relics and remains of Cairo can truly be considered as magnum opus in the field.

${ }^{8}$ Taqi al-Din Muhammad ibn Ahmad al-Husayni al-Fasi al-Makki, al- 'Aqd al-Thamin fi Tarikh al-Balad al-Amin, ed. Muhammad 'Abd al-Qadir Ahmad 'Ata', vol. 3 (Beirut: Dar al-Kutub al-'Ilmiyyah, 1998), 419 (See also other editions, e.g., edited by Muhammad Hamid al-Faqi, Cairo: Muhammad Sarur alSabban publisher, 1378 A.H., and Beirut edition by Mu'assasa al-Risala [n.d.]). al-Fasi also surveyed a number of oldest surviving mosques of his time in Taif and read their existing inscriptions; see, for instance, Shaf a al-Gar a $m$ bi Akhbar al-Balad al-Har a m, vol. 1 (Beirut: Dar al-Kutub al-'Ilmiyyah, 2002), 122 (See also other editions, e.g., edited by 'Umar 'Abd al-Salam Tadmuri [Beirut: Dar al-Kitab al-'Arabi, 1405]).

${ }^{9}$ Muhammad ibn 'Ali ibn Muhammad Jamal al-Din al-Makki al-Qarshi al-Shibi, al-Sharf al-A 'la $f i$ Dhikr Qubur Maqbira Bab al-Ma 'la, ms. no. 354 s.f. 1179 in King Sa'ud University Library, ms. no. $130 / 900$ in Shaykh 'Arif Hikmat Library in Madinah (copied in 1231/1816 by Ahmad al-Azhari), ms. no 18325 in National Library in Tunisia (copied in 891/1486 by Abu 'l-Qasim ibn 'Ali ibn Muhammad alQatani), ms. no. 6124 in Berlin Library (copied in 1122/1710 by Muhammad Sa'id ibn Isma'il al-Makki). It is interesting to note that the prominent family of Shibi earned fame and respect in Makkah during fifteenth century through their education and cultural activities. Quite a few of this clan hold various high positions in Makkah such as chief justice, mufti (deliverer of legal and religious verdict) and imam of the Grand Mosque. A number of scholars from this family taught at the famous Bengali religious seminary in Makkah named as al-Madrasa al-Sultaniyyah al-Ghiyathiyyah al-Bangaliyyah after its Bengali patron alSultan Ghiyath al-Din A'am Sh a h, the ruler of Bengal.
} 


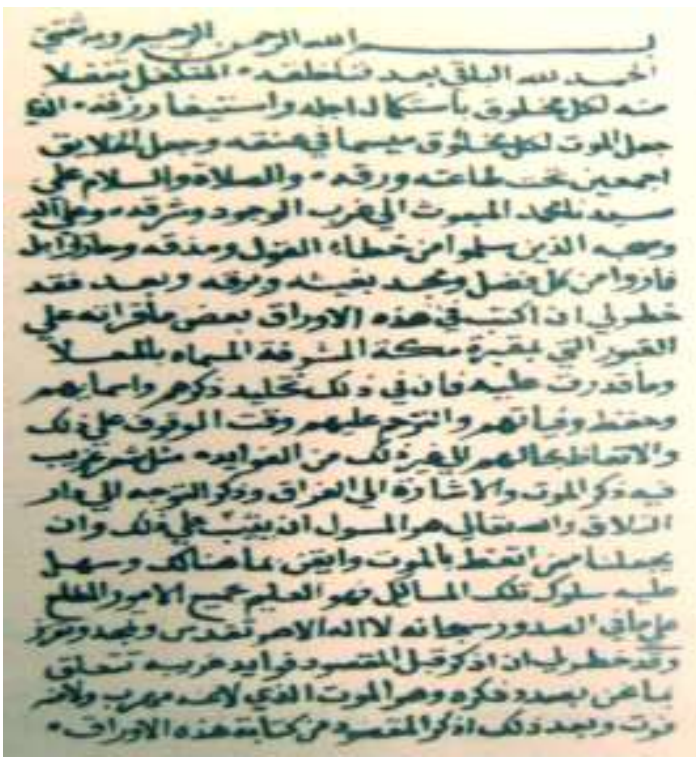

First folio from al-Shibi's ms. al-Sharf al- $A$ ' $l a$ '

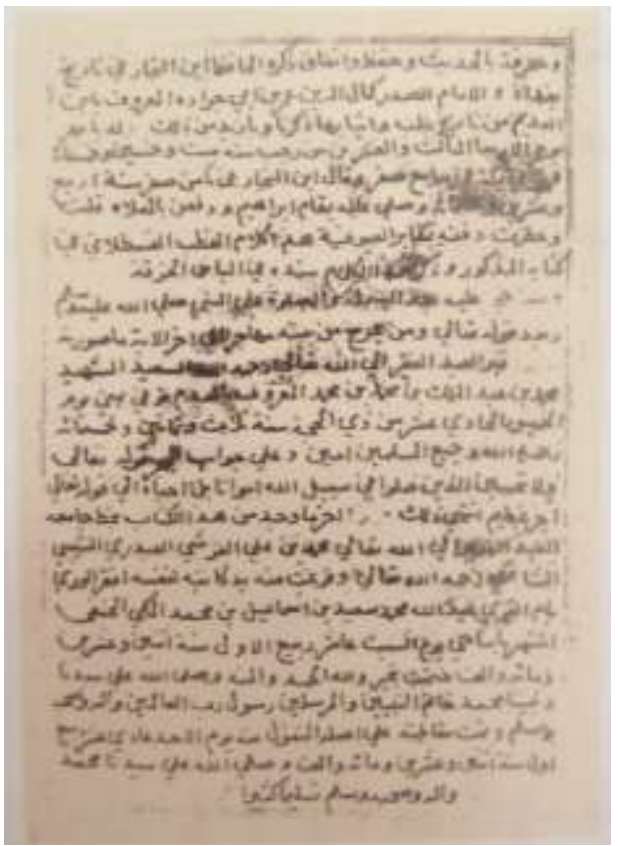

A folio from a different ms. of al-Sharf al- $A$ ' $l a$ ' 
He can truly be considered the father of epigraphy (شيخ در اسة النقوش الكتابية الأثربة). AlFasi used epigraphic evidences to fill the gaps in historical narratives while compiling his monumental work on the history of Makkah; al-Shibi looked at the inscriptions for their own sake - a strictly epigraphic approach. Not only did he painstakingly decipher a great number of tombstones in the graveyard of al-Ma 'la (popularly also known as al-Mu'alla), he also recorded such basic information as style of script, date, etc., exactly as a modern epigraphist would do.

However, approaching Islamic inscriptions in a systematic way with an academic interest began in the late nineteenth century, when Islamic epigraphy saw some of its rules codified as a result of the dedicated efforts of the famous Swiss orientalist Max Van Berchem (1863-1923) who can be regarded as the pioneer of the science of modern Islamic epigraphy in this age. The research methodology that he established for the study of Arabic inscriptions not only as an art form, also served as a scholarly field of considerable importance for oriental studies in the fields of language, history, art and architecture. Instead of just deciphering, reading, and translating inscriptions, a work of considerable skill by itself, he established the methodology of analyzing each inscription in its cultural and historical context, often culminating in a whole essay covering its particular time and space as well as biographical details of the names appearing in the epigraphic text. His pioneering works, such as Matériaux pour un Corpus Inscriptionum Arabicarum, ${ }^{10}$ certainly paved the way to establish Islamic epigraphy on sound footing. Soon after that, the monumental task of cataloging the Islamic inscriptions began with the publication of the Répertoire chronologique d'épigraphie arabe in 1931.

More than eight thousand inscriptions were edited in the first sixteen successive volumes of Répertoire (Cairo 1931-64) only, which covered the first eight centuries, and the effort continues to this day. In spite of the fact that Ré pertoire remains incomplete in a number of ways, partly because of the discoveries of a number of new inscriptions that came to light after its publication, still it can be considered one of the most useful inventories and the only existing attempt at a systematic grouping of Islamic inscriptions by year and in an approximately geographical order. Scholars such as Tychsen, Reinaud, J. J. Marcel, George C. Miles, S. Flury, Gaston Wiet, E. Herzfeld, A. Grohmann, Jean Sauvaget, Moritz Sobernheim, E. Lévi-Provença 1, J. Sourdel-Thomine and M. Y. Siddiq have contributed greatly in the field in the Western languages. On the other hand, Hasan Mohammed al-Hawary, Ibrahim Jum‘a, Hasan al-Basha, Zaki Muhammad Hasan, Abder Rahman Fahmy, M. Y. Siddiq and many others have contributed much in the Arabic language. A number of valuable works have also been rendered in other Islamic languages, particularly in Persian, Urdu, Turkish, Bengali, Pushtoo, Bahasa Malay and Bahasa Indonesia.

\footnotetext{
${ }^{10}$ Max Van Berchem, Matériaux pour un Corpus Inscriptionum Arabicarum, in Mémoires publiés par les Membres de l'Institut Français d'Arché ologie Orientale, (Egypte, vol. Xix, Cairo 1903; Jérusalem, vols, xliii, xlv, Cairo 1920-2; Syrie du Nord [in collaboration with E. Herzfield], vols. Lxxvi - lxxvii, Cairo 1955).
} 


\section{IMPORTANCE OF ISLAMIC EPIGRAPHY}

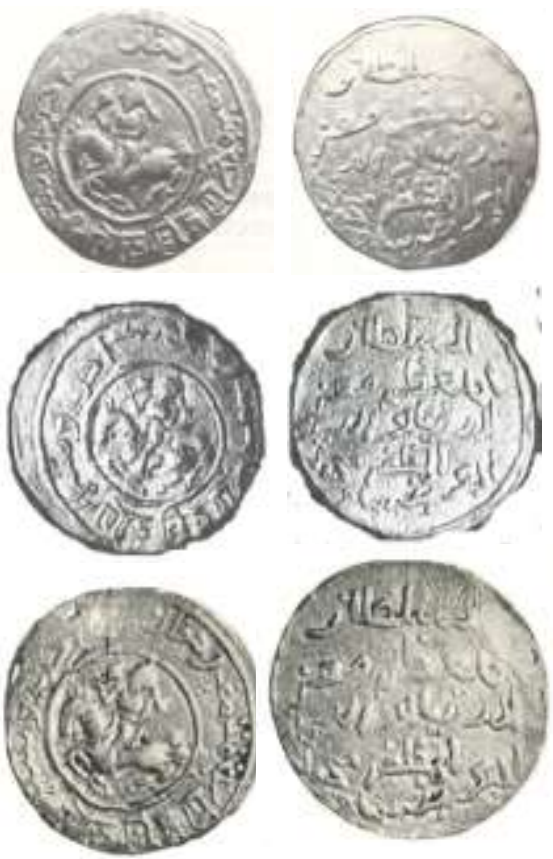

\section{Plate: First Islamic coins in Bengal issued by Bakhtiyar Khiliji}

Almost every inscription, whether on a milestone, frieze, or tombstone, contains useful information. The use of inscribed panels was and remains so common that it is difficult to imagine a building in an Islamic culture without one. In miniature painting, buildings are often shown decorated with inscribed panels. Architectural inscriptions are often large enough to catch the viewer's attention; in this way they interact directly with the aesthetics of their surroundings. The horizontal inscriptional band on the kiswa (the decorated black cloth used to veil the $K a$ ' $b a$ ) as well as the tiraz (a highly stylized form of embroiled writing on early Islamic textiles) may well have influenced and been influenced by architectural epigraphy. ${ }^{11}$

In many cases when a region came under Islamic rule or influence, for everyday use the local language was often retained, but Arabic was the official, religious, educational and literary medium.

In Central and South Asia, Persian was used in the royal courts, but Arabic remained the language of religion and therefore the lingua franca among Muslims. Islamic inscriptions across this vast land used both Arabic and Persian. Rulers used Persian, even though many came from a Turko-Afghan background and some spoke Turkic dialects. In South Asia, inscriptions in Turkish are rare since the conquerors

\footnotetext{
${ }^{11}$ One can argue of course that it was architectural epigraphy which influenced the Kiswa as well as the tirāz tradition in the Muslim world. In any case, some kind of mutual influence must have taken place at some stage.
} 
hardly ever used that language for writing. Out of the Indian languages, Sanskrit was used in rare cases both for numismatic and epigraphic purposes. The first coin issued by Ikhtiyār al-Din Muhammad Bakhtiyār Khalji commemorating his conquest of the Gaur region has inscription in both Arabic and Sanskrit. This suggests that the Muslim ruling class patronized the elite culture, perhaps at the cost of the popular one. The first and the third earliest inscriptions in Bengal, executed under the patronage of early Muslim rulers, namely Sultan 'Ala' Din 'Ali Mardan (607-610/1210-13) and Balka Khan Khalji (626-28/1229-31), are inscribed in Persian, while a khanqah inscription (dated 618/1221) from the reign of Ghiyath alDin 'Iwad from Sian, Birbhum District, not far from an early Islamic center of Lakhnawr, dated 618/1221 is rendered in Arabic. Bengal was one of the first and earliest regions to have Persian architectural inscriptions; especially after the establishment of Mughal rule in the region, Persian became the dominant language for inscriptions. That Persian was so used at so early a period in the Bengal frontier so far from both Persia and Central Asia, is intriguing.

\section{THEMATIC VARIETY OF ISLAMIC INSCRIPTIONS}

Inscriptions can be difficult to read, and much of the information in them may appear trivial to the uninitiated. Epigraphic sources rarely package and present information conveniently. Rather, they contain scattered bits of data, which need to be put together coherently with the help of other sources. However, one can gradually develop the skills and sensitivity that make their study both useful and interesting. From the point of view of political history, important data in an epigraphic text can be a date, a place name, or the name of the ruler recorded there. A historian can then try to incorporate all this fragmentary information into a historically coherent narrative. Such information can tell us that the area where the inscription was found was indeed under the jurisdiction of the ruler mentioned. If the name of the ruler in the inscription is different from the one usually found in contemporary chronicles, it might mean that some unusual event, such as rebellion, had taken place there which historians for some reason did not record. One such example is the Baramatyabari inscription of Bengal dated 934/1528, which records Mahmud Shah as being the sultan, even though the ruler of Bengal at that time was in fact Nusrat Shah. The inscription suggests that Mahmud Shah may have proclaimed himself the sultan in defiance of the authority of his brother - the ruling sultan - Nusrat Shah in 1528, though no such event is recorded in contemporary historical writings. Many violent events, especially those that went against the interests of the ruling establishment, were not recorded by an official chronicler at the imperial court, leaving the reader of the chronicle with the impression that peace and happiness prevailed throughout a ruler's reign. Generally speaking, dates on inscriptions are more reliable than dates in the texts of historical manuscripts, and therefore they provide valuable clues for reconstructing events in local history. While travelling in the famous city of Multan, the famed traveller Ibn Battuta saw an important inscription in an old Islamic edifice. Through this epigraphic text, he came to know that a ruler of the region Ghazi Malik fought twenty-nine wars against Mongol invaders. Ibn Battuta also noticed a commemorative inscription on 
the mihrab of the earliest Jämi'Masjid in Delhi, which he deciphered. This inscription helped him to find the exact date of the Muslim conquest of Delhi. ${ }^{12}$

Islamic inscriptions can provide sometimes some indispensable historical clues about the political history of a region. The names of quite a few rulers of the Bengal Sultanate can only be established on the basis of epigraphic evidence. Quite often, names of local administrators were not recorded by the imperial chroniclers living far away from the provinces. Inscriptions are sometimes the only source to furnish details of the local administration such as the names of revenue collectors, police officers, local army commanders and representatives of the central government in the area and their officials, names that would otherwise be lost to history. These names can be quite helpful as they can be analyzed and interpreted for historical purposes. Similarly, older or original names of places or administrative units and divisions in use when the inscription was made can be preserved, as can details bearing on social or religious history. Commemorative inscriptions sometimes tell us why the inscriptions themselves were made. The theme of sovereignty is historically associated with monumental entranceways, for example, because they were thought to be proper places to proclaim the sovereign's power. Epigraphic texts can also help us understand religious trends in a region.

While individual epigraphic text may vary, one can often sense a common ground of meaning, a unity of message. The inscription over a masjid entrance is apt to contain Qur'anic verses in praise of God, or other verses or Prophetic sayings that promise divine reward for those who construct and maintain masjids. Inscriptions on mihrabs will often use a verse in which the word mihrab (in Arabic) itself appears. The calligraphers also find a great source of inspiration, spiritually and aesthetically, in inscribing on religious buildings al-asma ' al-husna ' (the beautiful names of God), the basmala, and sometimes a poetic verse on a spiritual theme (usually in Persian, but sometimes also in Arabic). Sayings of the Prophet (hadith) start to appear on inscriptions towards the end of the eleventh century - there is a minbar inscription dated 484/1081 on the tomb of the head of Husayn, grandson of the Prophet, in Ascalon, which was later moved to the sanctuary in Hebron, Palestine. ${ }^{13}$ Mughal emperor Babar mentions in his famous autobiography, Tuzuk-iBabari known in Persian as Baburnama, an elegant inscription that used to decorate the facade of the central jami ' masjid (built by his ancestor, Amir Timur, next to his famous castle) in Samarkand. It contained an exquisitely written Qur'anic verse ( (يرفع إبراهيم القواعد , very popular among mosque inscriptions. Inscribed above eyelevel, this monumental inscription was nevertheless so large that, according to Babar, it could be seen from two miles away. Common elements in the inscriptions in different parts of the Islamic world indicate that a silent process of universalization of values and tastes was taking place in that world, along with the flow of merchants, travellers, hadith collectors, knowledge seekers and sufis.

\footnotetext{
${ }^{12}$ Ibn-Battuta, Rihla (Beirut; Dār Sādir, n.d.); 421.

${ }^{13}$ A number of writings of the famous epigraphist Max Van Berchem throw light on these issues. See for instance his article: "Note on the Graffiti of the Cistern at Wady el-Joz," Palestine Exploration Fund Quarterly Statement (1915): 85-90, 195-198.
} 
Both Qur'anic verses as well as hadith quoted in the epigraphic text can yield historical clues since they were selected for their appropriateness to a particular setting. Quite naturally, they contain some kind of religious message in the form of verses from the Qur'an or sayings of the Prophet (hadith). These messages can be very helpful in understanding religious trends and transformations in the region. The Throne Verse is often and appropriately used for funerary inscriptions and for calligraphy in mosques, as it is considered a source of baraka. ${ }^{14}$ A particular hadith is selected for an inscription on the same principle of appropriateness. So can names with religious connotations: the appearance of the names of the first four caliphs in an epigraphic text, for example, can be taken as evidence that the patron was a Sunni Muslim. If the patron of the building had been a Shi' $i$, only the name of 'Ali and the direct descendents of the Prophet $S A W$ (particularly the pāk panj tan or five holy bodies, a popular Shi'i invocation in South Asia) would appear. ${ }^{15}$ If, for example, the epigraphic text contains the terms of waqf (endowment), ${ }^{16}$ as is the case with an inscription from Nayabari, not far from Dhaka, dated 1003/1595 (see also another Waqf inscription of a Khanqah in Sitalmat, Bengal dated 652/1254), then the verse selected may contain messages promising rewards for those who look after the endowment and punishment for those who neglect or vandalize it.

The madad-i-ma' $\bar{a}$ sh inscription from Nayabari dated 1003/1595 also serves as a good example of how epigraphic panels were occasionally used to record legal documents such as waqf (endowment) deeds for mosques and madrasas. ${ }^{17}$ This tradition existed in certain parts of the Islamic world until the eighteenth century, no doubt in part because it had the practical advantage that stone slabs are less likely to perish or be stolen. There are a number of such inscriptions in Bengal, such as the Dohar inscription dated 1000/1591 and the Barakatra inscription dated 1052/1642 from Bengal. A complete waqf is inscribed in a building in Qazwin in Iran, for example. $^{18}$ In general, however, Muslims preferred paper for writing legal documents. Before the advent of the Muslims in Bengal (the first Muslim conquest under Ikhtiyar al-Din Bakhtiyar Khalji began in 601/1205), copper and other metal plates in general, and stone slabs in some rare cases, were used to record land grants and endowments in the region.

Tombstones and stelae can also furnish valuable information; they are sometimes the only authentic evidence we have for ethnic immigration to a particular region,

\footnotetext{
${ }^{14}$ The use of the Throne Verse for funerary inscriptions is quite common almost everywhere in the Muslim world. We find it, for instance, in the inscriptions on the täbut of al-Husayn dated 550 (1155) now in the Islamic Museum in Cairo.

${ }^{15}$ The Garh Jaripa inscription dated 893/1487; the Husayni Dalan inscription dated 1052/1642, and the Piyari Das Road masjid inscription dated 1109/1697 are good examples of this kind of epigraphic record. ${ }^{16}$ A number of such inscriptions have been discovered in Bengal. Of these, a Burarchar inscription and a Dohar inscription both dated 1000/1591 and now preserved in the Bangladesh National Museum, Dhaka, probably belong to the same edifice that is referred to in the Nayabari inscription. Other examples are a Gaur inscription dated 893/1489, now in the British Museum, and a Barakatra inscription dated 1055/1645, in Bangladesh National Museum.

${ }^{17}$ The institution of a waqf had certain advantages since waqf property could not be confiscated easily even by those in power.

${ }^{18}$ Sourdel-Thomine, "Inscriptions Seljoukides et salles a couples de Qazwin en Iran," Revue de Etudes Islamiques 42 (1974): 3-43.
} 
since the surnames, titles and more particularly the nisba (geographical attribution) of the deceased person on a tombstone will indicate the family's place of origin and the name of his tribe, such as Kabūli, Shirazi or Qaqshal. In addition, the stone may mention the profession of the deceased person or his social status, which can be useful for social and genealogical study. ${ }^{19}$ Most importantly, it furnishes us with the most authentic date of the death of the person for whom the tombstone was made.

Inscriptions are found on all kinds of structures - mosques, madrasas, khanqahs, shrines, mausoleums, forts, palaces, tanks, wells and caravanserais (see map), and are again often the most authentic record for the architectural chronology in Islamic civilization. Consequently, they are an important source for understanding the architectural activities of a particular region. Many are inscribed on a beautifully decorated background, and studying these decorative motifs can itself be rewarding. Sometimes, it plays a central role in architectural decoration (e.g. the gate inscription of Nim Darwaza at Miyanneh Dar dated 871/1466-67). Quite often, the effect of Islamic inscriptions can be sensed at the very first sight of a building. The majority of Islamic inscriptions record the circumstances of a building's construction, which allows us to date and to identify buildings and their functions. The calligraphic panels are usually so well blended into the overall decorative program that they seem to be an integral part of the architecture in many Islamic buildings, especially in Iran (e.g., Masjid-i-Mir in Mashhad), Central Asia (e.g., the Gur-i-Mir complex in Samarqand) and Turkey. In Bengal, however, it is somewhat different, as inscriptions are not completely blended into the aesthetic unity of the architecture; rather they remain distinctive in their appearance.

Diffusion of Islam meant diffusion of the use of Arabic as the primary religious and intellectual language. That a vast majority of epigraphs were inscribed in Arabic suggests that it had a strong impact on the cultural life of educated Muslims in general, as it was taught to high levels of proficiency in madrasas and other Islamic institutions in all regions. In Central and South Asia, however, Persian was also widely used. Both languages are accordingly found in Islamic inscriptions of Bengal. The likeness and affinity in the choice of language, layout, theme, literary style and taste in ornament, found in the Islamic inscriptions, point to a remarkable cultural coherence in the medieval world of Islam.

\footnotetext{
${ }^{19}$ In the Barakatra inscription dated 1055/1645, for instance, Abu 'l-Qasim al-Husayni (who endowed the edifice) uses the nisba al-Tabatab'i al-Simnani (from Tabataba and Simnan), and the calligrapher Sa'ad al-Din Muhammad uses the nisba al-Shirazi (from Shiraz). In a Nayabari inscription dated 1003/1595, Bhagal Khan, who endowed a masjid, is called Hajji (one who has performed pilgrimage).
} 


\section{GLOBALIZATION AND CULTURAL CONTINUITY OF THE ISLAMIC WORLD: COMPARISON OF THE INSCRIPTIONS OF BENGAL WITH THOSE OF ANDALUSIA}

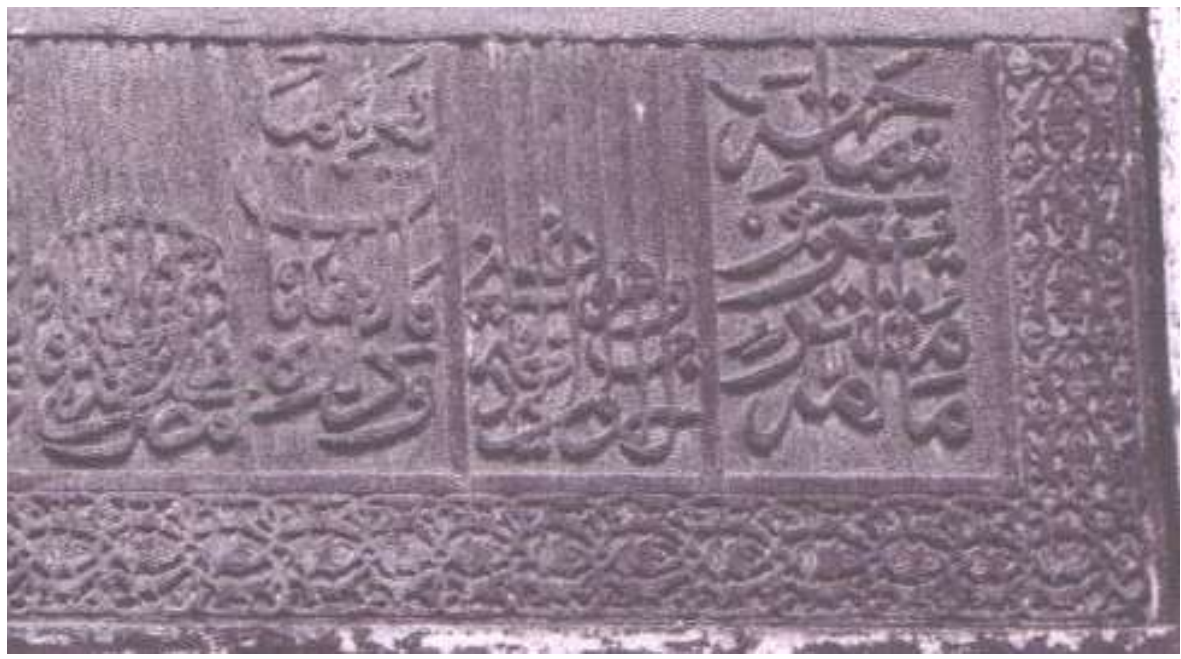

Plate: Second line of the Nim Darwaza inscription at Miyaneh Dar in Gaur, dated 871/1466-67

Two extremely interesting and exquisite inscriptions of Gaur dated 871/1466, that once belonged to two magnificent royal entrances to the Badshahi citadel in Gaur (namely, Nim Darwaza and Chand Darwaza) deserve special attention as they so closely resemble some fabulous eighth/fourteenth-century inscriptions that appeared at the other end of the Islamic world, in the Alhambra Palace in Granada. The literary style of the verses in these inscriptions has resemblance in a way in its composition with Qasida al-Burda of Imam al-Busiri. But since the purpose of these epigraphic texts is commemorative inscriptions, exactness of meter ( $\mathrm{Bahr}$ alBasit) in their poetic rhyme could not be observed throughout. It is striking indeed to note the conceptual and stylistic harmonies between these sets of inscriptions on royal monuments in Gaur and Granada, capitals of two different Muslim kingdoms thousands of miles apart. Both royal complexes were created over years to serve various functions - private palaces for the royals, mosques, public courts, castles and gardens. The inscriptions in both do not use the local vernacular but a very high quality of rhetorical, poetic Arabic for the texts. There is an interesting correspondence in the religious, social and cultural context - both capitals were inhabited largely by Muslims while the majority of the population in adjacent areas were non-Muslims. Grandiosity of the royal palace as well as water cosmology are among the prominent themes in many of the verses in the inscriptions of both Alhambra and Gaur. The river Darro ran by the side of Granada and a series of irrigational canals watered vast orchards of orange trees in and around Alhambra; several canals, lakes and water pools ornamented the lovely landscape of the royal palace of Gaur, with the old channel of the mighty Ganges flowing to the west of 
the palace. Reference to these water canals can be found in a verse in the Chand Darwaza inscription that is written as follows:

A watercourse flows beneath it, like the waters of Paradise, whose fruits take away need and pain.

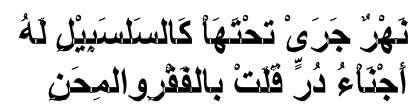

Likewise, the verses in the second line of the Nim Darwaza inscription echo the aesthetic aspects of Bārbak Shāh's palace, its monumental gate and the fabulous garden around it. The whole setting, compared with the Biblical garden of Eden ( (عَن ), is an earthly embodiment of the paradisial garden or janna (الجنة). Perhaps, the idea of janna (lit., garden) is more powerfully depicted in the Chand Darwaza inscription using the exact Qur'anic term salsabil (السلسبيل) or spring. Excavation by the Archaeological Survey of India on the site during 2002-2005 ${ }^{20}$ (adjacent to Baisgazi Wall of Gaur) clearly indicates the existence of an elaborate system of water channels, cisterns and aqueducts that crisscrossed the surrounding gardens of the magnificent wooden palace, finally to merge with the river Ganges in the west. One of these canals passes through a hidden interior tunnel, running intricately through the middle of the palace, before it links up to a magnificent jetty of a river port at the back of the palace facing the Ganges.

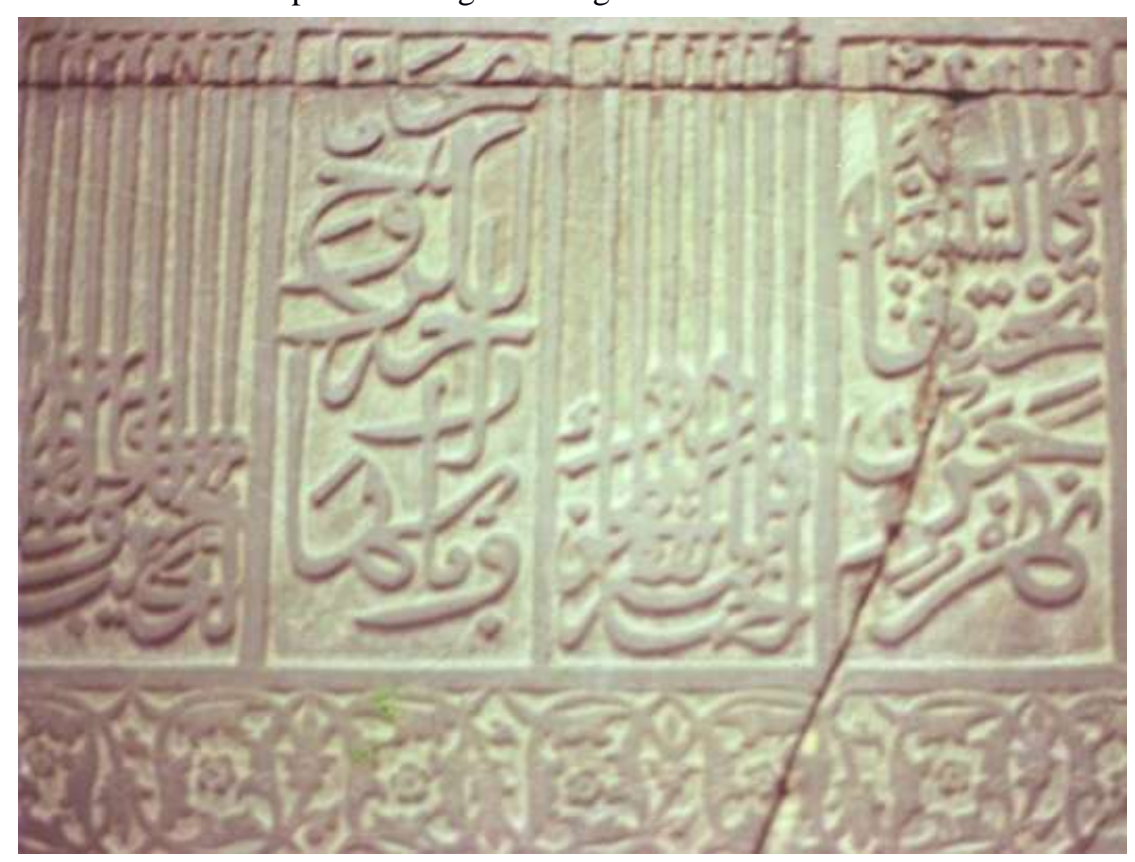

Plate: Four verses from the second line of the inscription at Miyaneh Dar in Gaur, dated 871/1466-67

\footnotetext{
${ }^{20}$ Bimal Bandyopadhyay "Recent Excavation of the Area adjacent to Baisgazi Wall of Gaur and Scientific Clearance at Some Adjacent Areas, District, Malda, West Bengal", Journal of Bengal Art, volume 9-10 (2004-2005, published in 2006): 12-23.
} 
Interestingly, the concept of gardens with pools and fountains dominates the theme of a number of verses in the inscriptions of the Alhambra palace in Granada. The Court of Lions was embellished with a majestic water-fountain alluded to metaphorically in the verses inscribed within the palace. One of the verses (inscribed on the Hall of Ambassadors written by the vizir lisan al-Din al-Khatib), runs in Arabic.

Likewise, the verses in the second line of the Nim Darwaza inscription echo the aesthetic aspects of Bārbak Shāh's palace, its monumental gate and the fabulous garden around it. The whole setting, compared with the Biblical Garden of Eden (جَيَّة عدنن), is an earthly embodiment of the paradisial garden or janna (الجنة). Perhaps, the idea of janna (lit., garden) is more powerfully depicted in the Chand Darwaza inscription using the exact Qur'anic term salsabil (السلسبيل) or spring. Excavation by the Archaeological Survey of India on the site during 2002-2005 ${ }^{21}$ (adjacent to Baisgazi Wall of Gaur) clearly indicates the existence of an elaborate system of water channels, cisterns and aqueducts that crisscrossed the surrounding gardens of the magnificent wooden palace, finally to merge with the river Ganges in the west. One of these canals passes through a hidden interior tunnel, running intricately through the middle of the palace, before it links up to a magnificent jetty of a river port at the back of the palace facing the Ganges.

Interestingly, the concept of gardens with pools and fountains dominates the theme of a number of verses in the inscriptions of the Alhambra palace in Granada. The Court of Lions was embellished with a majestic water-fountain alluded to metaphorically in the verses inscribed within the palace. One of the verses (inscribed on the Hall of Ambassadors written by the vizir lisan al-Din al-Khatib), runs in Arabic as follows:

Whoever approaches me complaining of thirst, I offer him a cool and satisfying drink, unmixed and pure

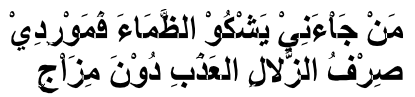

Similarly, in the verses of ibn Zamrak inscribed on the Fountain of the Lions, we find a similar metaphor when it says:

Haven't you noticed the rhythm in the gushing water,

that runs creating graceful currents descending from above

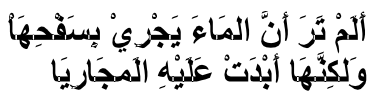

Water is projected in all these verses as a fascinating aspect of the art that gave these monuments a special meaning. We also find several other metaphors referring to water cosmology in a number of other verses by ibn Zamrak inscribed in different places of Alhambra, such as al-ibriq (إلبريق) or jug and ina' al-ma' (إناء الماء) or water vessel. While Burj al-Ma' (بزج الماء) or Tower of Water, that used to glorify one of the compounds of Alhambra vanished long ago, Fana' al-Birka (فناء البركة) or

\footnotetext{
${ }^{21}$ Bimal Bandyopadhyay "Recent Excavation of the Area adjacent to Baisgazi Wall of Gaur and Scientific Clearance at Some Adjacent Areas, District, Malda, West Bengal” Journal of Bengal Art, volume 9-10 (2004-2005, published in 2006): 12-23.
} 
the 'Court of the Cistern' along with the 'Room of the Ship' exist to this day to remind us of the aesthetic beauty of water. Similarly, Bab al-Shari 'a (باب الثريعة) or Gate of Justice also carries the same allusion in that shari ' $a$ can mean a source of drinking water. The front court of Alhambra, a starting point of the whole complex, was known as Fana' al-Rayhan (فناء الريحان) or Rayhan (lit., basil/mint) Court, where basil and mint plants adorned the view. The term rayhan appears in a verse in the Chand Darwaza inscription that runs:

Its gate provides refuge, like fragrant basil to the soul, to friends, while to foes it is forbidden and remote

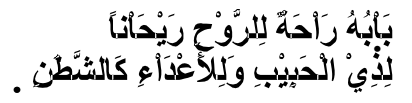

The inscriptions of both Miyāneh Dar in Gaur and Alhambra give expression to basic drive of rulers and ruling classes everywhere, and in every age for power and glory, which lose their meaning unless exclusive. Nothing is known about the first line on the upper half of the Nim Darwaza inscription that disappeared long ago without trace. But one can easily imagine that it contained verses referring to the unparalleled glory of Sultan Bārbak Shāh's power and his fabulous palace. Indeed, several verses in the Chand Darwaza inscription as well as in the remaining part of the Nim Darwaza inscription glorify the majestic rule of the sultan and the exemplary grandiosity of the royal palace. The thematic similarity with a number of verses in Alhambra inscriptions is striking. For example, we find these verses in the latter:

$O$ son of kings, and of the sons of kings, whose power the stars submit when your origins are compared

When you erect a palace, there is no equal to it; it

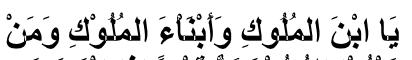

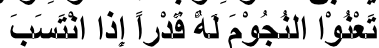

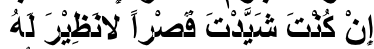
achieves

such a glory that all the other glories are subdued by it.

A similar theme can be found in the inscription which once decorated the two lion head shaped spouts in the Alhambra bath that end with the following two verses:

Blessed be he who gave the Imam Muhammad a mansion which in beauty exceeds all other mansions

Here is the Garden containing wonders of art the like of which God forbids should elsewhere be found.

Verses in Chand Darwaza inscription praising Barbak Shah as an unmatched and incomparable king on the earth run as follows:

Is there in the two Iraqs a sultan as generous, As Bārbak Shāh, or in Syria and in Yaman. No! There is not unto him in all God's land, An equal in generosity, for he is unique, unparalleled in time.

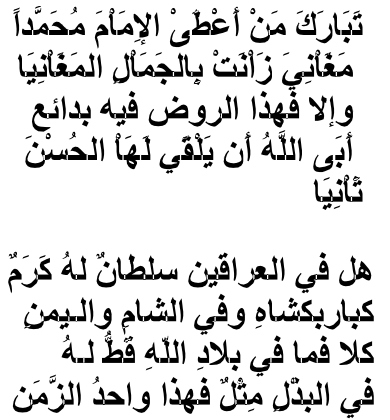


Chand Darwaza (lit., 'Moon Gate' in Bengali) was a prominent gate in Sultanate palace of Gaur; al-Burj al-Qamari (lit., 'Moon Tower' in Arabic) was an important architectural element in Alhambra. While we recognize the great diversity in the regional cultural expressions in the Islamic world, at the same time we also find a remarkable cultural continuity, as if ideas travelled from Islamic East to Islamic West, at least in spiritual sense, if not literally. With the spread of Islamic civilization, a gradual globalization was taking place in the old world, albeit silently.

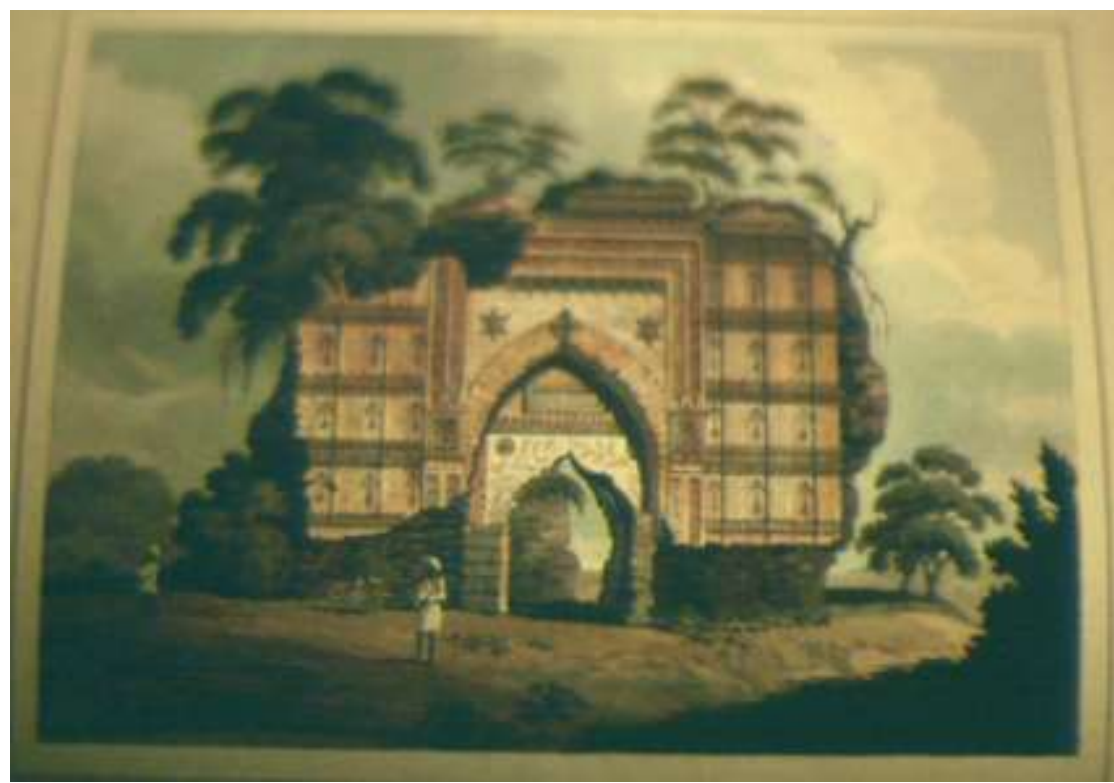

Plate: Chand Darwaza towards the end of the eighteenth century as depicted by Creighton in his drawing "Ruins of Gaur"

Though use of poetical motifs became common in Persian inscriptions (particularly in Bengal since the advent of the Mughals in the sixteenth century), they were rarely used before this period in Arabic inscriptions. These poems were especially composed to reflect the glamour of royalty, whether in Alhambra or in the palace citadel of Gaur. We may consider them as topical, as explanatory of the purpose of the building, referring not only to specific elements of the palace (e.g., the monumental gates), but also to its unique setting. ${ }^{22}$

Among the distinctive aspects of these two different epigraphic programs, we notice that the inscriptions of Alhambra are at eye level, for instance, around the niches of the walls. Artistically they are well-harmonized with the overall decorative scheme of the building. On the other hand, both the Nim Darwaza and Chand Darwaza inscriptions in the Gaur citadel were placed quite high above eye level, making

\footnotetext{
${ }^{22}$ For a detailed and in-depth discussion on the meaning and metaphor of verses in Alhambra inscriptions, see Oleg Grabar, The Alhambra (Sebastopol, California: Solipsist Press, 1992), 75-129.
} 
them difficult to read except by special effort by a handful of learned people (e.g., 'ulama') in the area. While we know the names of those who composed the different verses inscribed in Alhambra palace, namely, ibn Zamrak (verses on the Rayhan [Basil] Court), ibn al-Jayyab (verses on two halls adjacent to the Rayhan [Basil] Court), and lisan al-Din al-Khatib ${ }^{23}$, we know nothing about the poets who composed the beautiful verses either in the Chand Darwaza or Nim Darwaza inscriptions. While much of Alhambra complex is still intact, very little of the sultanate palace complex in Gaur remains extant.

\section{EPIGRAPHY OF MUSLIM BENGAL}

Bengal has an epigraphic heritage extending back to the pre-Islamic period. Inscriptions of various styles are evident in this region, which was once rich in stone carving and sculpture. In the pre-Islamic period, however, artists and craftsmen did not use their skill to exhibit calligraphy as such; Sanskrit and Pali inscriptions are generally informative rather than calligraphic in intent.

Inscriptions became more common after the advent of Islam in Bengal and as Bengali Muslim rulers launched into architectural projects. It is difficult to imagine a building of that period without some kind of inscription; it was as if it would have appeared naked or unfinished without it. As a result, epigraphic records and inscriptions are plentiful in terms of both artistic accomplishment and historical information.

Historical accounts of the Islamic dynasties in South Asia are numerous, particularly those regarding the central authorities in Delhi. A number of sourcebooks, most in Persian, record the deeds of sultans and emperors. Bengal, however, has a very small share of this rich heritage of historical writing. Whatever might once have existed, of that very little has survived. One example of a lost source is a Persian manuscript on early Muslim rule in Bengal found by Francis Buchanan Hamilton in a shrine in Pandua in the early nineteenth century and mentioned in his book, A Geographical, Statistical and Historical Description of the District or Zilla of Dinajpur in the Province or Soubah of Bengal (Calcutta, 1833). Unfortunately, the manuscript cannot be traced. Several factors, including natural calamities such as flood and fire, may account for the lack of extant sources. The prolonged monsoons and generally humid weather in Bengal pose an additional challenge to the preservation of archives.

\footnotetext{
${ }^{23}$ James Cavanah Murphy, History of the Mahometan Empire in Spain, London, 1816 (See English translation of the Arabic inscriptions of Alhambra in appendix by Shakespeare under the title: A Collection of the Historical Notices and Poems in the Alhambra of Granada); Jules Goury and Owen Jones, Plans, Elevations, Sections and Details of the Alhambra, 2 v., London: 1842-45; Sabih Sadiq, “Qasr al-Hamra':Diwan Shi 'ri Manqush ‘Ala' 'l-Jidran”, al-Faysal, no. 353 (December 2005), 54-67).
} 


\section{EARLY ISLAMIC CONTACT WITH BENGAL}

Another important factor in accounting for the scarcity of materials on the history of Muslim Bengal was the attitude of imperial chroniclers in Delhi towards this region - very few were keen to record events there because it was so remote from the capital. What was recorded in writing usually reflected the official version of

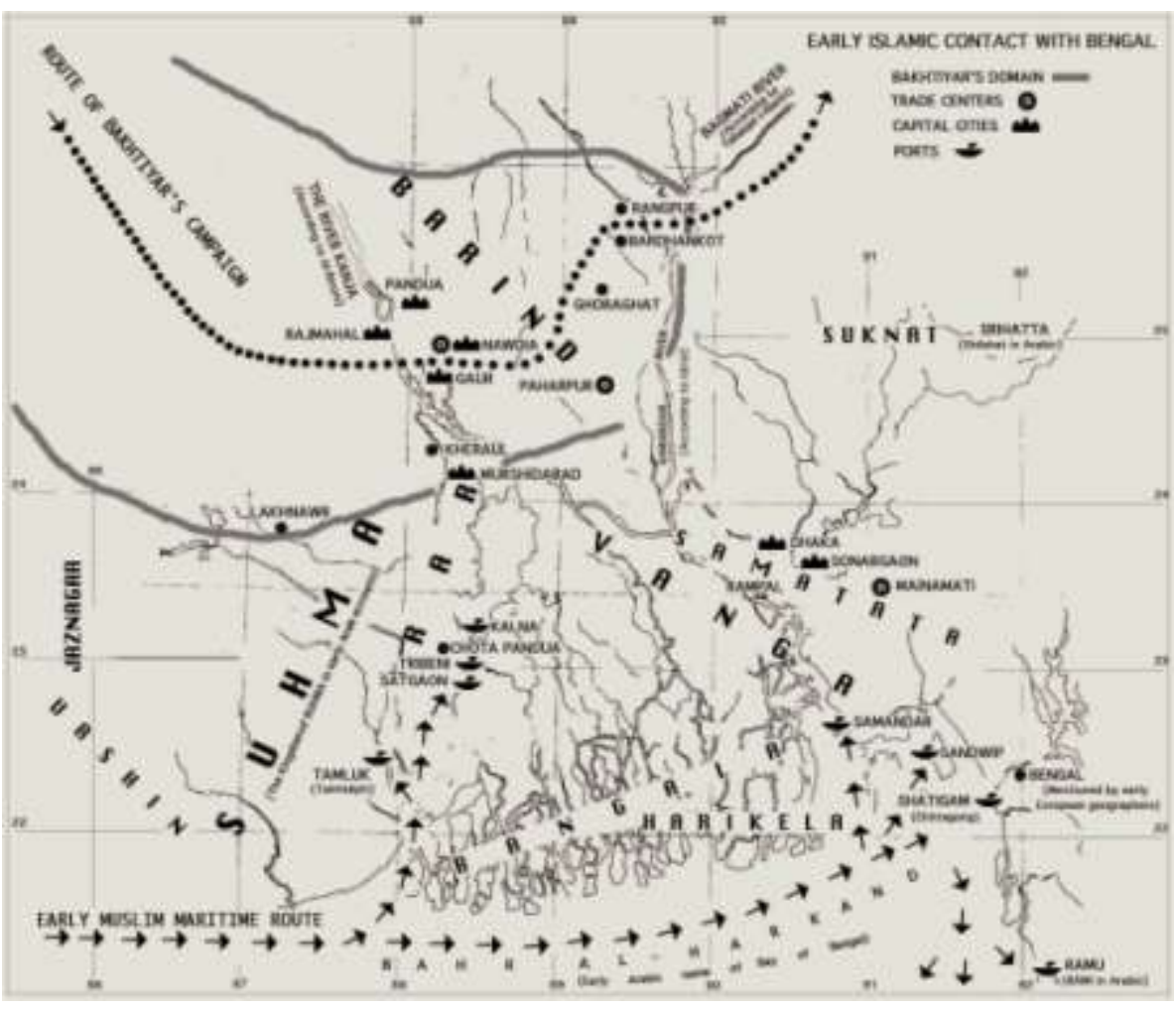

events, such as military expeditions to subdue the region, as there was always a temptation for the governors to rebel. Written in the capital, these texts exhibit not only a generally urban bias, but also the views of the central government; thus, they seldom provide reliable information on the region.

Though the epigraphic heritage of Bengal fills many gaps left by earlier historians, its study did not begin until the second half of the eighteenth century, when some Muslim 'ulama' (often known as Munshi or Mawlavi in traditional Bengali society) began to take a scholarly interest in deciphering the texts. The first scholar to realize the importance of epigraphic evidence for dynastic history and to use it as a source for dating different historical monuments and architectural remains was Sayed Ghulam Hussein Salim Zayedpuri (d. 1817). He lived in Ingrezbazar (Malda) near Gaur, the ruined early Muslim capital of Bengal which abounded in inscriptions. He was a pioneer of Islamic epigraphy who examined inscriptions for the first time with great academic interest as early as the mid-eighteenth century. While compiling Riyad al-Salatin - the history of Bengal - (completed in 1788, published 
in Calcutta by the Asiatic Society of Bengal in 1893), he studied the epigraphic materials of Gaur and used them in constructing a chronology of Bengal's ruling dynasties. However, it was Sayyid Munshi Ilahi Bakhsh al-Husayni Awrangzebadi, an indirect disciple of Sayed Ghulam Hussein who systematically examined a significant number of the Islamic inscriptions of Gaur, Pandua and adjacent areas. In total, he deciphered forty-two inscriptions with astonishing accuracy, most of them for the first time. He used this epigraphic evidence in writing the history of Muslim rule in Bengal which formed a substantial part of his ambitious project of writing the history of the world. Part of this monumental Persian work - Khurshid-iJahan Numa - covered the history of Muslim rule in Bengal, and was edited and published, with an English translation by Henry Beveridge in the Journal of the Asiatic Society of Bengal in 1895. Interestingly, one of Munshi Ilahi Bakhsh's students, Abid Ali Khan, also took a great interest in the inscriptions of Gaur and Pandua as is evident in both of his works, Short Notes on the Ancient Monuments of Gaur and Pandua (Malda, 1913) and Memoirs of Gaur and Pandua (edited by H. E. Stapleton, Calcutta, 1931).

Early in the nineteenth century, British collectors began to take an interest in these inscriptions, motivated principally by their visual appeal. For many of them, colonizing of lands and peoples also meant the colonizing of their arts, architecture, archaeological heritage, and even interpretation of their history and culture. Most of the private as well as museum collections of this period were built upon works removed from their context and often illegally or improperly acquired. However, as interest in Oriental antiquities and art objects developed in the West, many Europeans set out to explore ancient sites in search of them. Cities such as Gaur and Pandua attracted a number of such adventurers, many of whom were little more than plunderers, or at best antique collectors. Some, however, left accounts and diaries of their experience, most of them are now preserved in the India Office Library in London, which provide a rich source for materials on inscriptions that no longer exist.

Foremost among the British scholars pioneering this field is Sir Henry Creighton who lived for twenty years (1786 - 1807), near Gaur and wrote a book, The Ruins of Gaur (London, 1817) illustrated with fabulous sketches and architectural drawings. He often refers to inscriptions he found in the old Islamic monuments of the area. Another celebrated British collector of oriental antiquities was Major William Franklin who visited Gaur at the beginning of the nineteenth century. Both his diaries, Journal of a Route from Rajmahal to Gaur and The Ruins of Gaur, preserved in the India Office Library (Mss. nos 19 and 285), give a clear description of the archaeological remains in the region and record a number of inscriptions. The collection that he took with him to England consisted of many monumental inscriptions, some of which he gave to the British Museum. The most elegant piece in this collection, however, found its way through antique dealers to the United States, where it ended up in the museum of the University of Pennsylvania in Philadelphia.

Franklin was accompanied on his tour by a local guide named Munshi Shayam Prasad, a scholar of Arabic and Persian. At Franklin's request, he prepared a report 
on the archaeological remains of the area. It, too, has become a valuable source for the epigraphy of the region (Ms. 2841 in the India Office Library, later published by A. H. Dani as an appendix to his book, Muslim Architecture of Bengal [Dhaka: Asiatic Society of Pakistan, 1961)]. Another contemporary archaeologist, named Orme, also left a brief report, The Ruins of Gaur, now in the India Office Library (Ms. 65: 25), which describes a few inscriptions. Francis Buchanan Hamilton was another early nineteenth-century scholar who noted a number of inscriptions during his tour of the district of Dinajpur in 1807-08. He mentions some of them in his work A Geographical, Statistical and Historical Description of the District or Zilla of Dinajpur.

In the second half of the nineteenth century, the investigation of the art and archaeology of the region became more scholarly. One of the first studies of this period was by Captain W. N. Lees, who published an Arabic inscription of Sultan Barbak Shah in the JASB in 1860. Among the important studies of that time is Gaur, Its Ruins and Inscriptions by J. H. Ravenshaw (London, 1878), which is particularly rich in illustrations and texts. The formation of the Archaeological Survey of India in 1861 brought a revolutionary change to the archaeological study of South Asia. Its first director general, Sir Alexander Cunningham, and his subsequent colleagues, took systematic steps to record all existing inscriptions. Other scholars to discover Islamic inscriptions of Bengal during this period were Dr. James Wise, Mr. E. Vesey Westmacott, Mr. Hili and Mr. Walter M. Bourke. Many of the rubbings they collected were sent to the Asiatic Society of Bengal in Calcutta, where scholars such as Henry Blochmann deciphered and published them.

Among other scholars to contribute to this field in the late nineteenth and early twentieth centuries were R. D. Banerji, Henry Beveridge, H. E. Stapleton, S. Aulad Husain, Rahmat Ali Taish, Hamid Allah Khan and Khan Sahib Moulvi Abdul Wali. At the end of the nineteenth century, the Archaeological Survey of India established a separate section for epigraphy and began to publish its specialized series, Epigraphia Indica. Epigraphia Indo-Moslemica, devoted entirely to the Muslim inscriptions of India, issued its first volume in 1907-08. Eminent scholars such as Ghulam Yazdani, Paul Horn, Denison Ross and J. Horvitz either participated in its editing or contributed scholarly articles. After independence from the British, its name changed to Epigraphia Indica, Arabic and Persian Supplement. Scholars such as Ziauddin Desai published a number of inscriptions from Bengal. Two important works were published before the independence of Bangladesh and certainly provided models for a comprehensive epigraphic study of the region. The first was Bibliography of Muslim Inscriptions of Bengal by A. H. Dani (published as an appendix to Journal of the Asiatic Society of Pakistan, vol. 2 (1957)), and the other Inscriptions of Bengal by an eminent twentieth-century epigraphist, Maulvi Shamsuddin Ahmad (Rajshahi: Varendra Research Museum, 1960). Among recent publications, Corpus of Arabic and Persian Inscriptions of Bihar (Patna: Jayaslal Research Institute, 1973), by Qeyamuddin Ahmad, and Corpus of the Arabic and Persian Inscriptions of Bengal (Dhaka: Asiatic Society of Bangladesh, 1992), by Abdul Karim, a prominent historian of Bangladesh, are indeed important additions to this genre. Recent publication of a monumental Arabic work Rihla ma' $a$ al- 
Nuqush al-Kitabiyya al-Islamiyya fi Bilad al-Bangal: Darasa Tarikhiyya Hadariyya is an important addition to this field and contains an elaborate discussion of almost 400 inscriptions. ${ }^{24}$ All of these works have enriched the field of epigraphy of the region.

The Islamic inscriptions of Bengal during the period 1205-1707 number roughly 400. Unlike the pre-Mughal Arabic inscription, Mughal inscriptions are usually in Persian. Most of them are architectural, recording construction of mosques, madrasas, khanqahs, shrines, mausoleums, etc. Quite naturally, they contain some kind of religious message in the form of verses from the Qur'an or sayings of the Prophet (hadith). These messages can be very helpful in understanding religious trends and transformations in the region. One of the primary goals of the present study is to capture these messages and to interpret them in their proper contexts. Hence this book not only affects the old approaches, but also brings fresh results consequently enhancing the understanding of the region's history.

The Islamic inscriptions of Bengal provide historical clues about early Muslim rule in the region. The names of quite a few rulers of Bengal during this period can only be established on the basis of epigraphic evidence. Inscriptions also furnish details of the local administration such as the names of revenue collectors, police officers, local army commanders and representatives of the central government in the area and their officials, names that would otherwise be lost to history. These names deserve special attention as they can be analyzed and interpreted for historical purposes.

Also interesting is the diffusion of Islam in this region, which led to the growth of the use of Arabic and Persian. Islamic epigraphic texts serve as one of the primary sources for understanding the early spread of Islam in Bengal as they shed new light on the religious and cultural dynamics of a crucial period of Bengali history. It helps us understand the complex history of the consolidation of Islam in a region which, despite its having no direct geographical link with the rest of the Islamic world, has a strong Islamic identity and plays an important role in the Islamic world.

\footnotetext{
${ }^{24}$ Mohammad Yusuf Siddiq, Rihla ma'a 'al-Nuqush al-Kitabiyya al-Islamiyya fi Bilad al-Bangal:
} Darasa Tarikhiyya Hadariyya (Damascus: Dar al-Fikr, 2004). 


\section{APPENDIX \\ A COMPARATIVE LOOK INTO A FEW INSCRIPTIONS FROM VARIOUS REGIONS OF SOUTH ASIA}

(1)

\section{Khanqah Inscription from Dunyapur, Pakistan Dated 600 (1204)}

Original Site:

Current Location:

Material, Size:

Style, No. of Lines:

Reign:

Language:

Type:

Reference:
Khanqah and Shrine of Sayyid Ahmad Kabir near the town of Dunyapur near Multan, Lodhran District, Punjab, Pakistan

In Situ.

Cut and dressed (terracotta) inscriptions on bricks; Not known.

Crude form of naskh resembling to some extent riqa; 10 lines.

Sulman Shihab al-Din (Mu'iz al-Din) Muhammad (1174-1206) of Ghazna and the first formal Muslim ruler of Northern India.

Arabic.

Dedicatory inscription.

Professor Abdul Rehman, "Paying Tributes to the Saints: The Tomb of Sayyid Ahmad Kabir" 


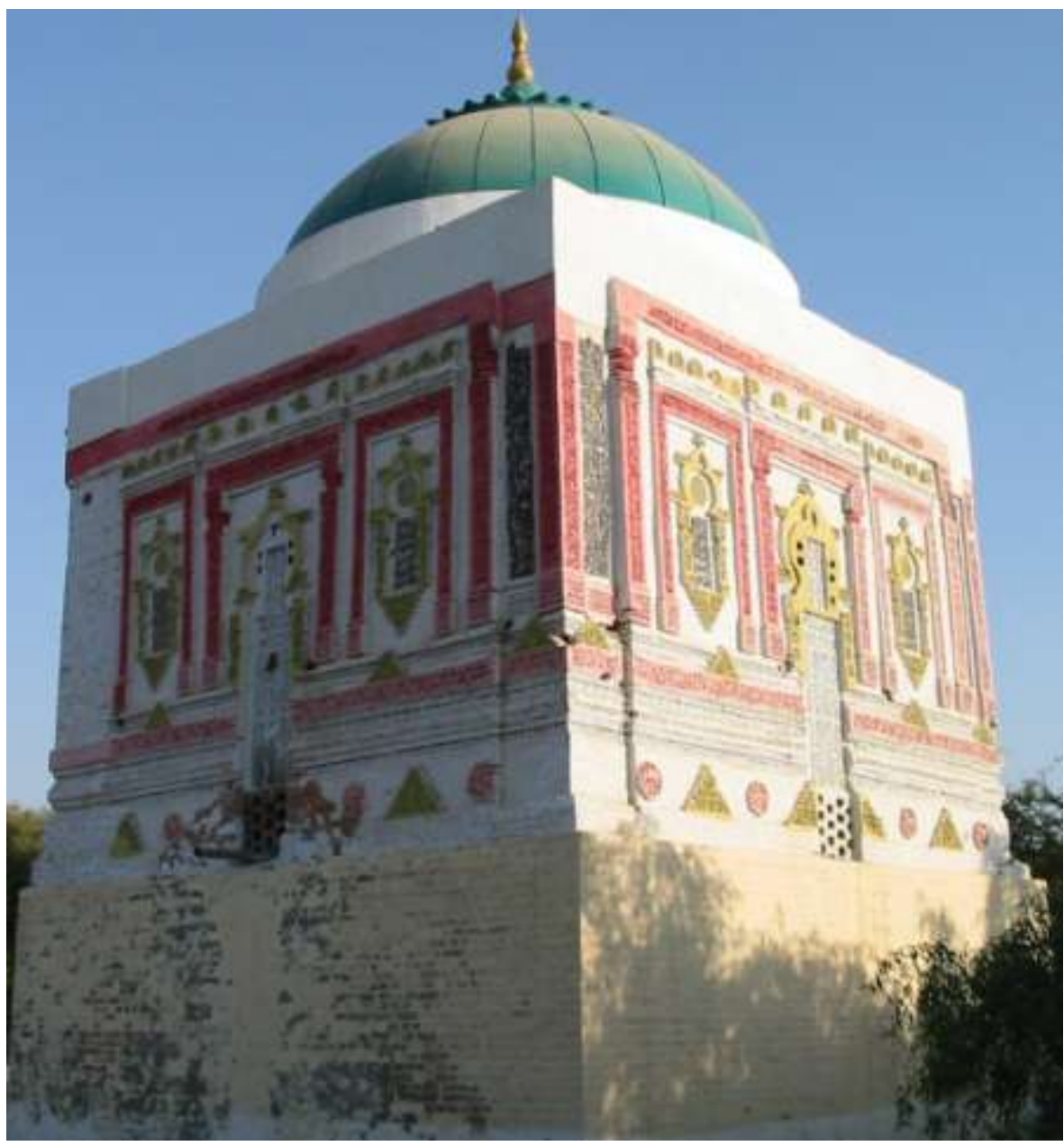

Plate A: A View of the Tomb from the South West Corner

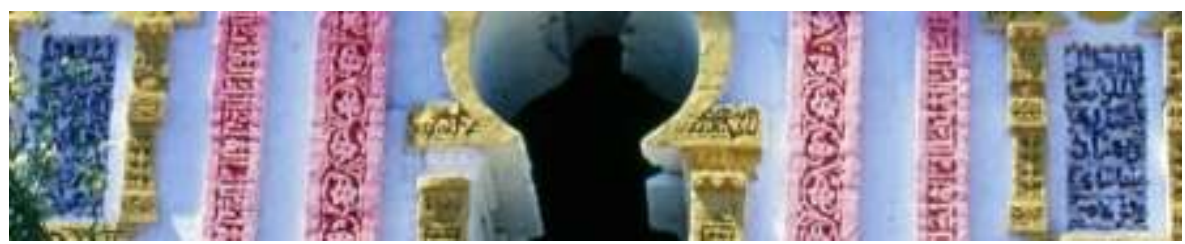

Plate B: A View of Arabic Inscriptions on the Eastern Façade 


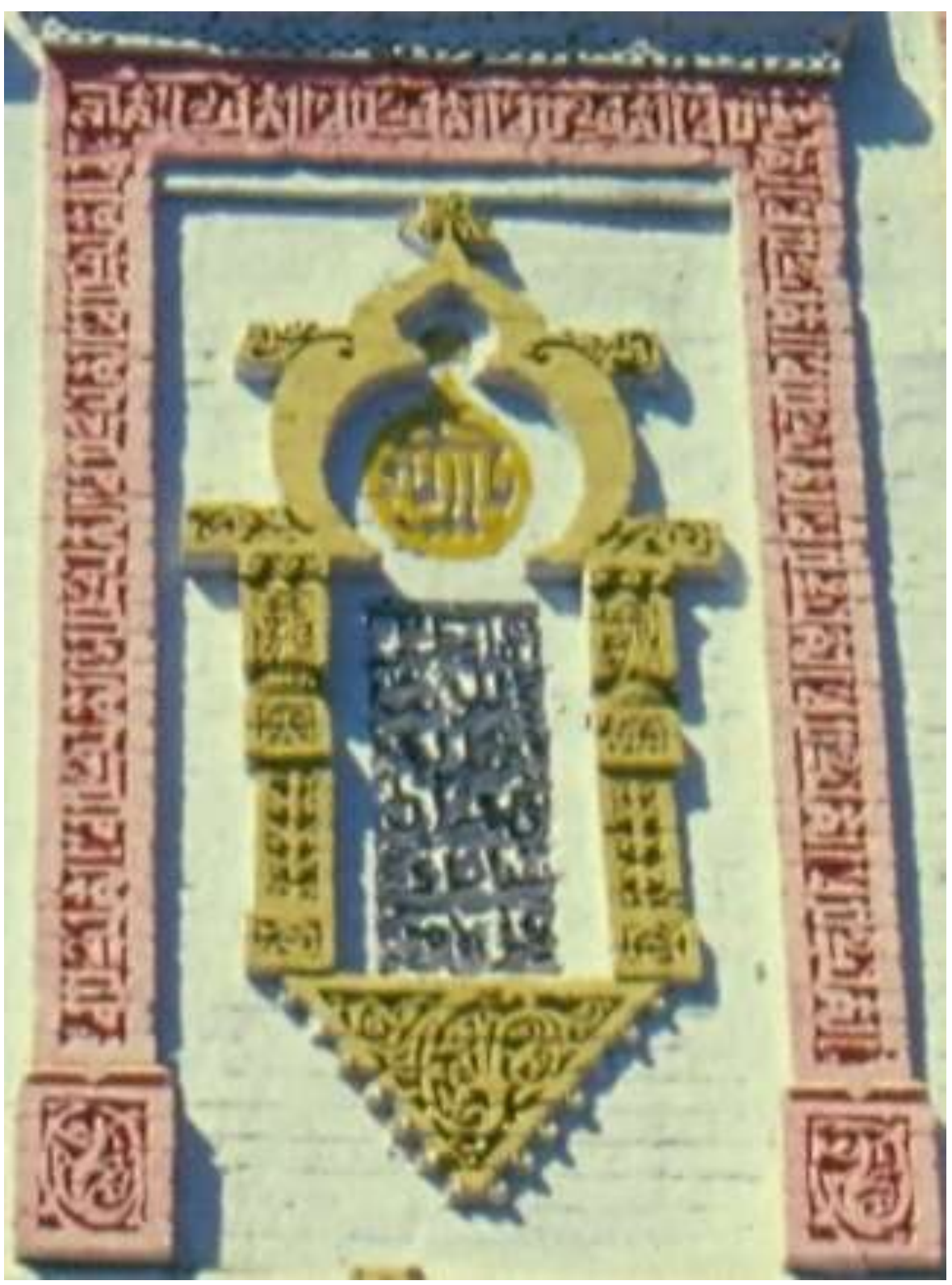

Plate C: A detailed view of an Arabic inscription on the eastern façade in naskh style with bands of Kufi writing on the top, at the right and the left sides 


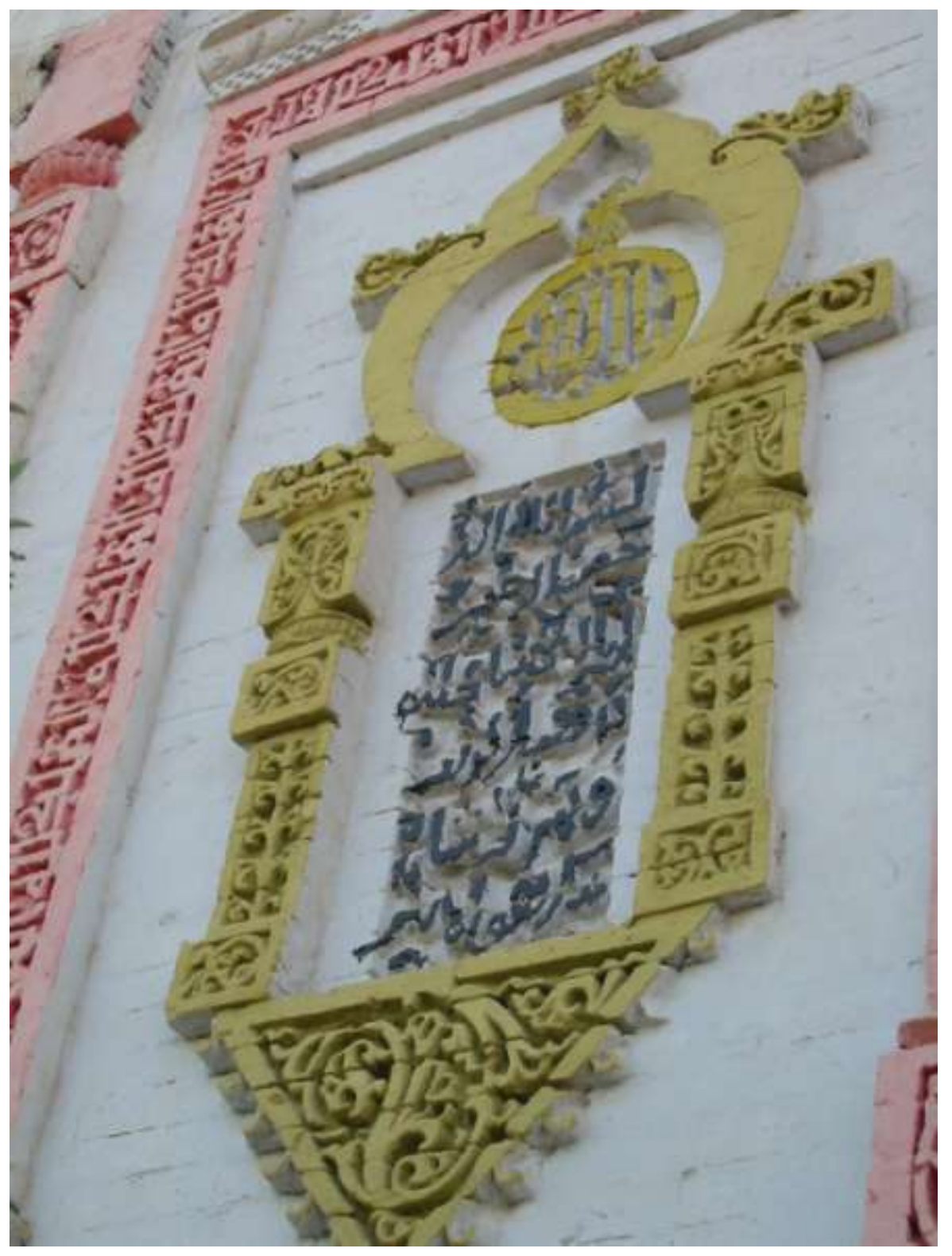

Plate D: A detailed view of the above-mentioned inscription 


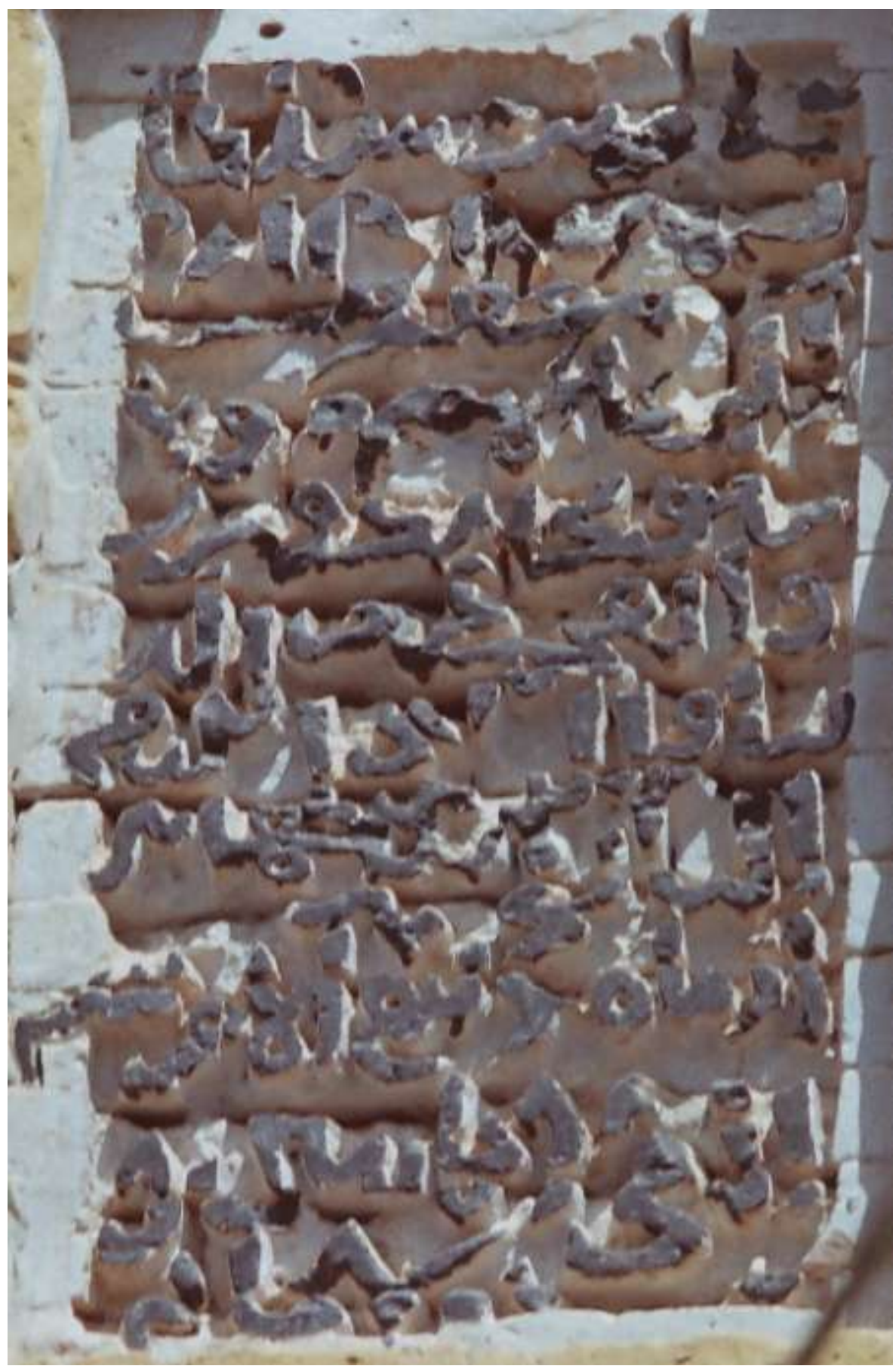

Plate E: A close view of the inscription under discussion 


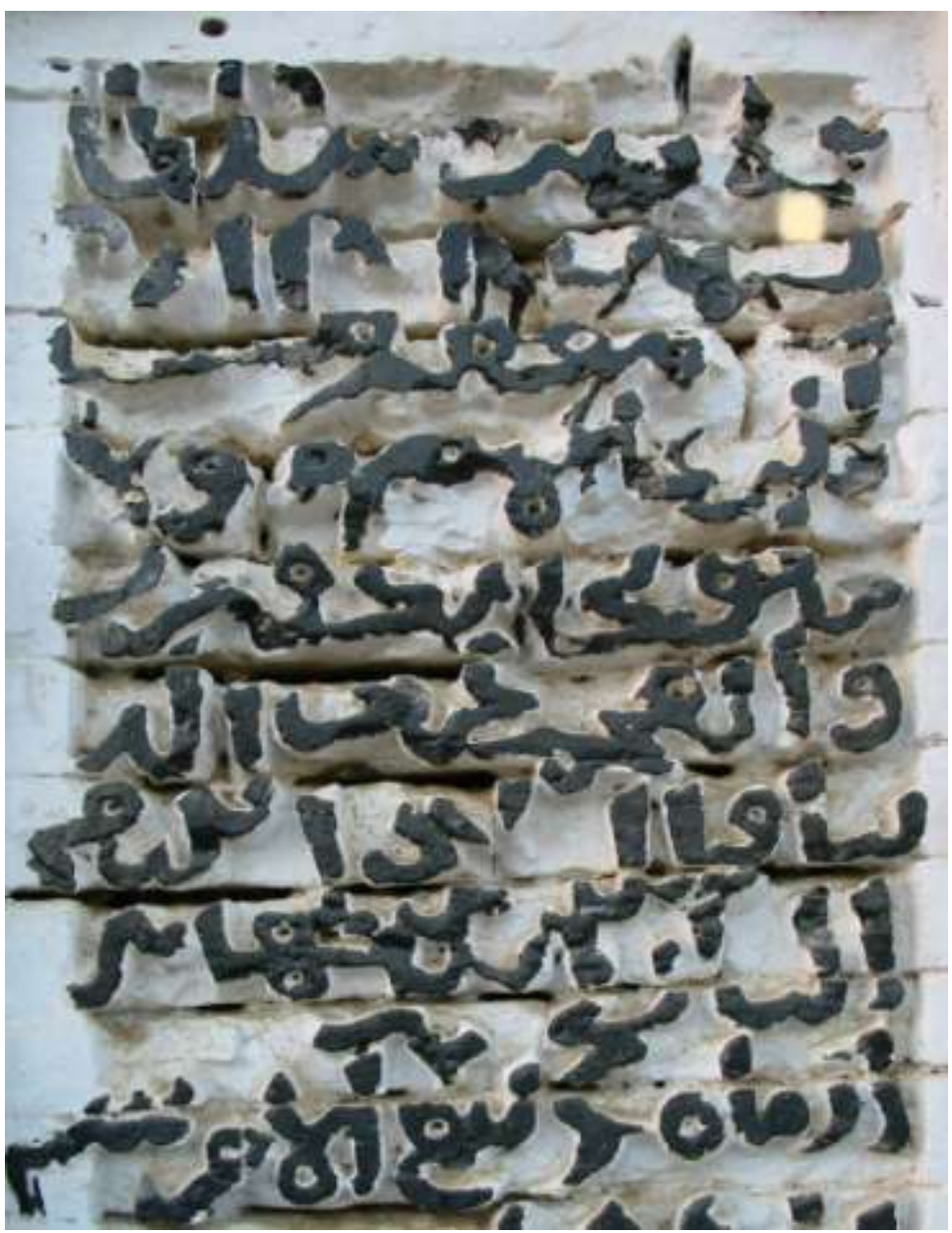

Plate F: Another view of the inscription under discussion 


\section{TRANSLATIONS}

L -1 The Emir . . . the Sultan

L -2 the great . . al-Malik

L -3 May Allah forgive all of them

L -4 This took place during the reign of the

'Amir al-'Arab

L -5 wa 'l-'Ajm 'Akram al-Du-

L -6 -nya wa '1-Din Ashhar

L -7 al-Bayan Shihab al-Din

L -8 during (the month of) Rabi' al-Awwal

L -9 And that was in the Hijra year

L -10 Six hundred

\section{TEXT}

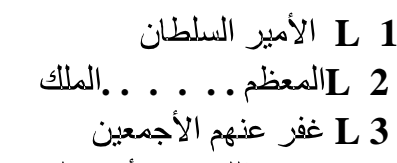

L 4

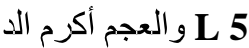

L 6

L البيان شهاب الدين

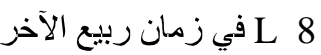

L 9 و اكان ذلك في السنة الهجرية

L ستماية L 10

\section{DISCUSSION}

It was Dr. Abdul Rehman of the Department of Architecture at the University of Engineering and Technology who drew my attention to this extremely interesting and one of the earliest Arabic inscriptions of South Asia. The shrine has a few other Arabic inscriptions, in addition to a number of inscriptions in Sharda script widely used in those days in the region, including some of the Ghaznavid coins of Sultan Mahmud unearthed in Lahore. It was Sharda script which is believed to be the origin of Gurumukhi script extensively used for writing Punjabi in the Easter Punjab state of Modern India. One of these inscriptions in Sharda script in this edifice records the name of the patron and donor for the shrine as well as some scanty information about an endowment for the shrine. 
One of the earliest areas in Punjab and Sind to come into contact with Islamic civilization and culture, the area is rich in Islamic art, architecture and inscriptions. Followings are a few more examples of some of the earliest Arabic inscriptions in the region:

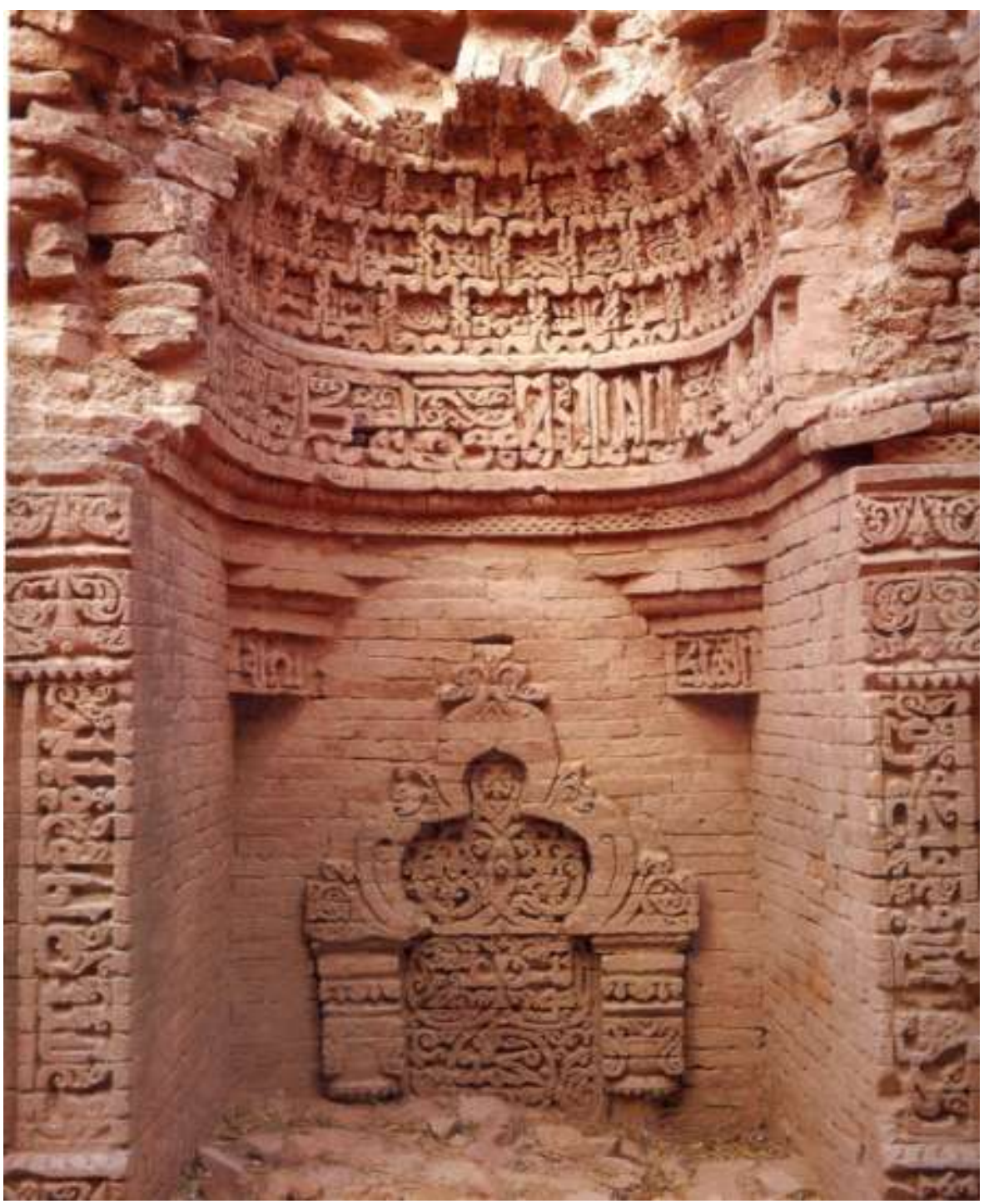

Mihrab of a ruined ancient mosque near the tomb of Khalid Walid in the village of Khattichor, Kabirwala, Multan, Punjab, Pakistan 


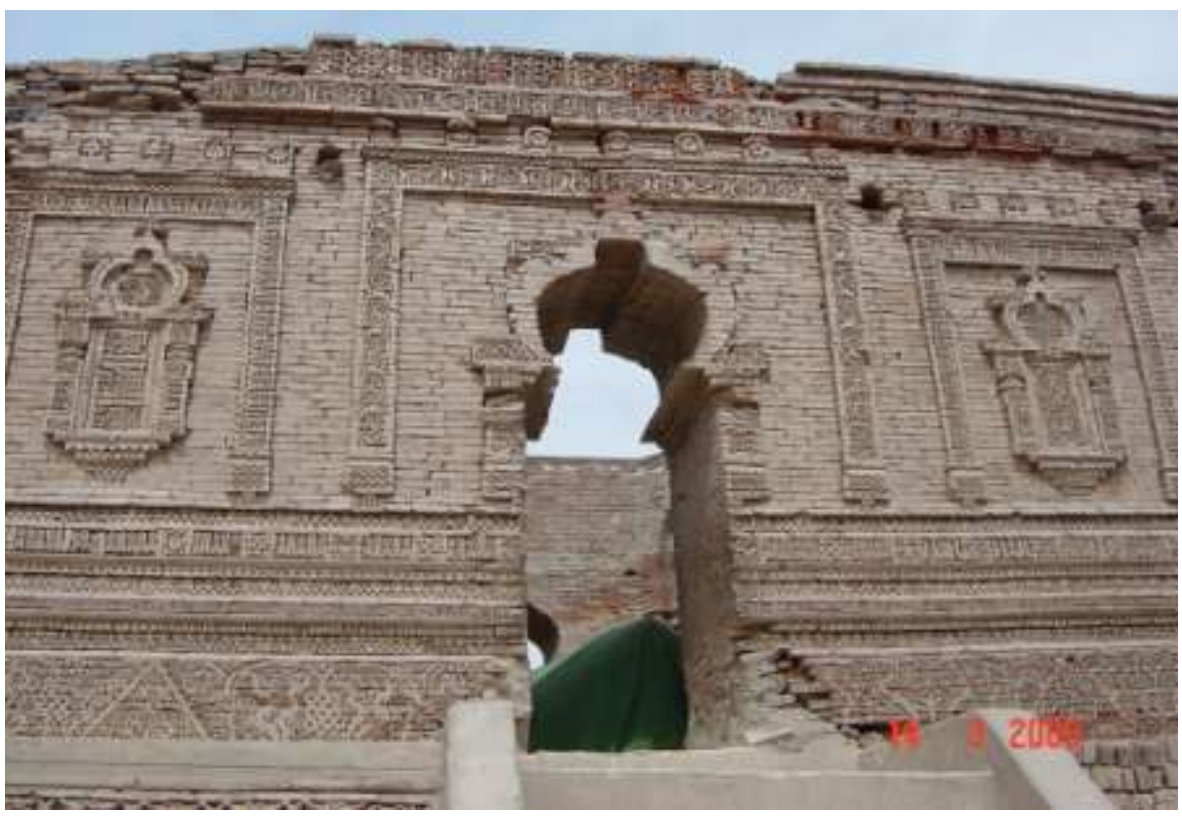

Plaited Kufi inscription decorating the façade of the tomb of Shaykh Sadan Shahid, located at the distance of 12-14 miles from Muzaffargarh city, near Multan, Pakistan.

(2)

A Garden Inscription in Ahmadabad Dated 1027 (1618)

Original Site:

Current Location:

Material, Size:

Style, No of Lines:

Reign:

Language:

Type:

Publication:
A Mughal garden not far from the present city of Ahamdabad in Gujarat, India.

British Museum, London.

White marble slab.

nasta 'liq; 5 lines.

Jahāngīr (1014-1037/1605-27)

Persian.

Commemorative inscription.

None. 


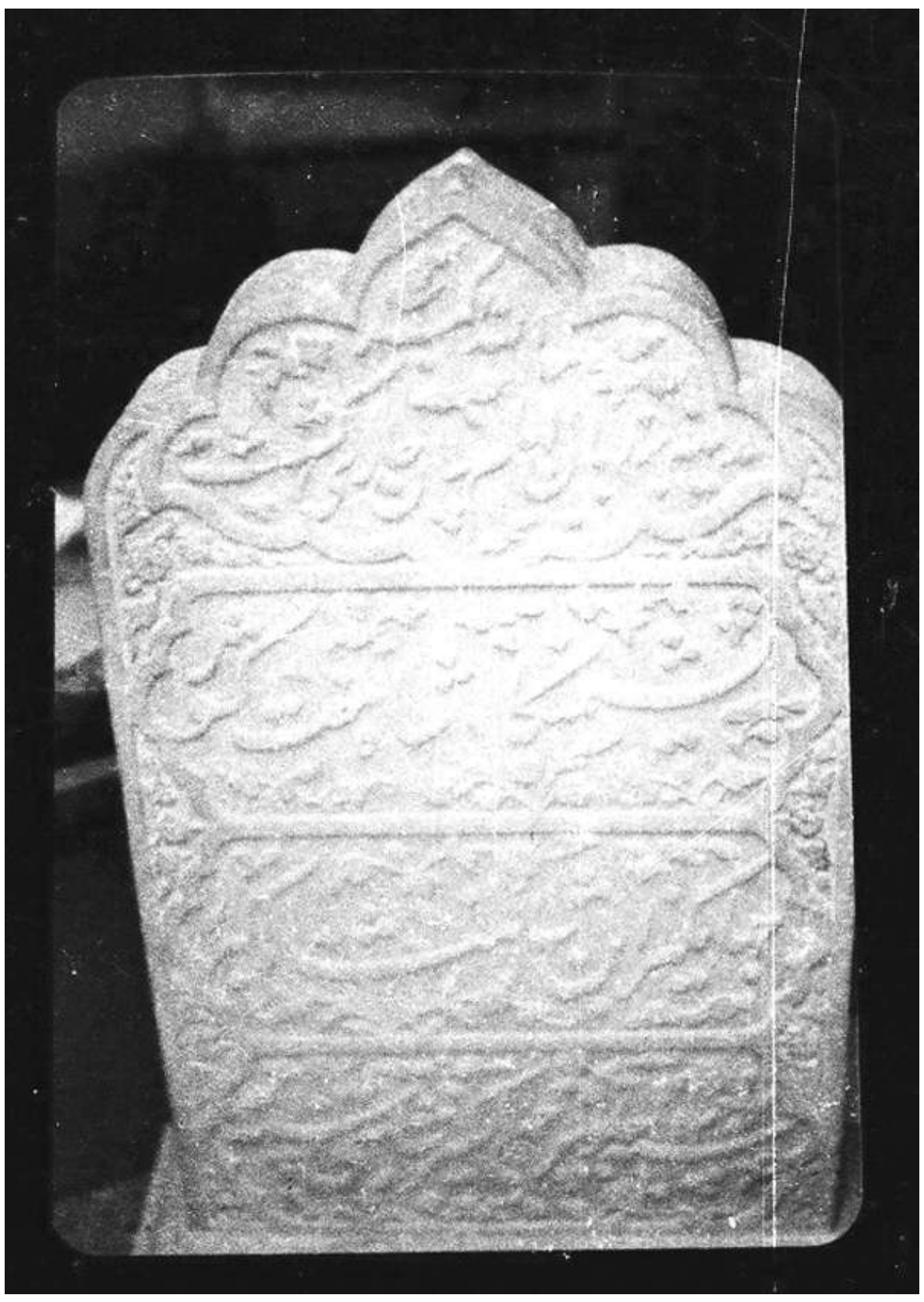

Plate: A Garden inscription in Ahmadabad in Gujrat 


\section{TRANSLATION}

L-1 Allah is the Most High!

L-2 An expression came suddenly from the inspired tongue.

L-3 The resting place of the emperor of the seven climates.

L-4 Jahangīr, son of the emperor Akbar.

L-5 [In the] $12^{\text {th }}$ regal year of the accession of Jahangir, the year 1027.
TEXT

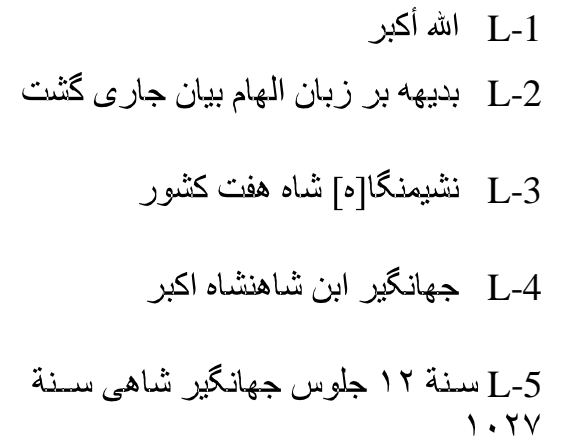

\section{DISCUSSION}

This is the only inscription in this book from Gujarat in the far western region of the Subcontinent which was once visited by the Mughal emperor Jahangir. Thus the inscription provides us an opportunity for a comparative look into the Islamic epigraphic heritage elsewhere in South Asia. While there is cultural continuity in the epigraphic expression in the Islamic world, there is also a certain diversity which makes each region's epigraphy unique.

This unnoticed inscription in the British Museum is mentioned by Jahāngīr in his memoir, Tuzuk Jahangiri. ${ }^{25}$ He describes how he had felt tired on a trip to Ahmadabad and decided to take rest in a nearby garden. ${ }^{26} \mathrm{He}$ was about to lean his back against the trunk of an old tree when he saw a hole which did not please his imperial taste. The emperor immediately ordered this hole filled with a marble slab which he thought should be inscribed with verses commemorating his stay there. Such was the imperial taste! Being in a cheerful mood, the emperor composed the first verse, but in spite of his best effort he could not complete the second hemistich. His court poet finally rescued him and finished it off.

The polylobed-shaped marble slab itself is visually very appealing. Its background is richly decorated with different floral and foliated designs. Each hemistich is further decorated with cartouches on both sides. Calligraphically, it presents a very high standard of nasta 'liq style.

\footnotetext{
${ }^{25}$ Tuzuk Jahangiri , Urdu trans. Mawlaw Ahmad 'Ali Rāmpuri (Lahore: Sang-e-Meyl Publications, 1977), 283.

${ }^{26}$ Khankhanan 'Abd al-Rahim, the son of Bayram Khān and the commander-in-chief of emperor Akbar, created this fabulous garden for his daughter Janān Bibi.
} 


\section{SELECTED BIBLIOGRAPHY}

1. al-Husayni al-Fasi al-Makki, Taqi al-Din Muhammad ibn Ahmad. al- 'Aqd alThamin fi Tarikh al-Balad al-Amin, edited by Muhammad 'Abd al-Qadir Ahmad 'Ata', vol. 3. Beirut: Dar al-Kutub al-'Ilmiyyah, 1998.

2. Bandyopadhyay, Bimal. "Recent Excavation of the Area Adjacent to Baisgazi Wall of Gaur and Scientific Clearance at Some Adjacent Areas, District, Malda, West Bengal", Journal of Bengal Art, 9-10 (2004-2005 published in 2006): 12-23.

3. Berchem, Max Van. Matériaux pour un Corpus Inscriptionum Arabicarum, in Mónoires publiés par les Membres de l'Institut Français d'Archéologie Orientale. Egypte, vol. Xix, Cairo 1903; Jérusalem, vols, xliii, xlv, Cairo 19202; Syrie du Nord [in collaboration with E. Herzfield], vols. Lxxvi - lxxvii, Cairo 1955.

4. Berchem, Max Van. "Note on the Graffiti of the Cistern at Wady el-Joz", Palestine Exploration Fund Quarterly Statement (1915): 85-198.

5. Ettinghausen, R. "Arabic Epigraphy: Communication or Symbolic Affirmation." In Near Eastern Numismatics, Iconography, Epigraphy and History: Studies in Honor of George C. Miles, ed. D. K. Kouymjian. Beirut: American University of Beirut, (1974): 297-317.

6. Goury, Jules and Owen Jones, Plans, Elevations, Sections and Details of the Alhambra, 2 v., London: 1842-45.

7. Grabar, Oleg. The Alhambra. Sebastopol, California: Solipsist Press, 1992.

8. Ibn 'Ali al-Maqrizi, Taqi al-Din Ahmad. al-Khitat wa 'l-Athār. Cairo, 1370 A.H.

9. Ibn-Battuta, Rihla. Beirut; Dār Sādir, n.d.

10. Jamal al-Din al-Makki al-Qarshi al-Shibi, Muhammad ibn 'Ali ibn Muhammad. al-Sharf al-A 'la fi Dhikr Qubur Maqbira Bab al-Ma 'la, ms. no. 354 s.f. 1179 in King Sa'ud University Library, ms. no. 130/900 in Shaykh 'Arif Hikmat Library in Madinah (copied in 1231/1816 by Ahmad al-Azhari), ms. no 18325 in National Library in Tunisia (copied in 891/1486 by Abu 'l-Qasim ibn 'Ali ibn Muhammad al-Qahtani), ms. no. 6124 in Berlin Library (copied in $1122 / 1710$ by Muhammad Sa'id ibn Isma'il al-Makki.

11. Murphy, James Cavanah. History of the Mahometan Empire in Spain, London, 1816.

12. Sadiq, Sabih "Qasr al-Hamra':Diwan Shi'ri Manqush 'Ala' 'l-Jidran”, alFaysal, no. 353 (December 2005): 54-67.

13. Shaf a al-Gar a $m$ bi Akhbar al-Balad al-Har a $m$, vol. 1. Beirut: Dar al-Kutub al-'Ilmiyyah, 2002.

14. Siddiq, Mohammad Yusuf. Rihla ma 'a 'al-Nuqush al-Kitabiyya al-Islamiyya fi Bilad al-Bangal: Darasa Tarikhiyya Hadariyya Damascus: Daar al-Fikr, 2004.

15. Siraj al-Din, Mawlana Minhaj al-Din. Tabaqāt-i-Nāsiri', ed. 'Abd al-Hay Habibi. Kabul, 1342 A.H.

16. Sourdel-Thomine, "Inscriptions Seljoukides et salles a couples de Qazwin en Iran", Revue de Etudes Islamiques 42 (1974): 3- 43.

17. Tuzuk Jahangiri, Urdu trans. Mawlawi Ahmad 'Al' Rāmpūri. Lahore: Sang-eMeel Publications, 1977 